NOAA

National Marine

Fisheries Service
Fishery Bulletin

¿ established 1881 ๙
Spencer F. Baird

First U.S. Commissione of Fisheries and founder of Fishery Bulletin
Abstract-Coral reef fisheries have a cultural, economic, and ecological importance and sustain the societal well-being of many coastal communities. However, the complexities of the multigear, multispecies fisheries that target coral reef species pose challenges for fisheries management. We focus on the Guam shore-based coral reef fishery 1) to evaluate the characteristics of the past and recent fishery in terms of catch composition and effort per gear type and 2) to reconstruct the reef-fish population in shallow (depths $\leq 30 \mathrm{~m}$ ) water during 1985-2012. To accomplish this, we used the results from a detailed creel survey conducted by the Guam Division of Aquatic and Wildlife Resources. The total estimated effort has stayed more or less stable; however, the estimated total catch has dropped from an annual mean of 100 metric tons (t) during the period $1985-1990$ to $37 \mathrm{t}$ during the period 2007-2012. Catch per unit of effort (CPUE) declined for most gear types between the 2 time periods. Reconstruction of historical targeted fish biomass, based on CPUE, showed a general decrease in biomass from 1985 to 2012. Biomass quickly dropped to about half of the 1985 values, then leveled off for a decade before declining again beginning in 2003 and continuing through 2012 .

Manuscript submitted: 30 April 2015. Manuscript accepted: 2 March 2016. Fish. Bull. 114:237-256 (2016). Online publication date: 18 March 2016. doi: 10.7755/FB.114.2.9

The views and opinions expressed or implied in this article are those of the author (or authors) and do not necessarily reflect the position of the National Marine Fisheries Service, NOAA.

\section{Trends in biomass of coral reef fishes, derived from shore-based creel surveys in Guam}

\author{
Mariska Weijerman (contact author) 1,2 \\ Ivor Williams ${ }^{3}$ \\ Jay Gutierrez ${ }^{4}$ \\ Shanna Grafeld 5 \\ Brent Tibbatts 4 \\ Gerry Davis6
}

Email address for contact author: mariska.weijerman@noaa.gov

1 Joint Institute for Marine and Atmospheric Research

School for Ocean and Earth Science and Technology

University of Hawaii at Manoa

Marine Science Building 312

1000 Pope Road

Honolulu, Hawaii 96822

2 Environmental System Analysis Group

Wageningen University

P.O. Box 47

6700 AA Wageningen, Netherlands

${ }^{3}$ Coral Reef Ecosystem Program

Ecosystem Sciences Division

Pacific Islands Fisheries Science Center

National Mariner Fisheries Service, NOAA

1845 Wasp Boulevard, Building 176

Honolulu, Hawaii 96818

\author{
${ }^{4}$ Division of Aquatic and Wildlife Resources \\ Guam Department of Agriculture \\ 163 Dairy Road \\ Mangilao, Guam 96913 \\ 5 Department of Natural Resources and \\ Environmental Management \\ University of Hawaii at Manoa \\ 1910 East-West Road \\ Sherman Laboratory 101 \\ Honolulu, Hawaii 96822 \\ 6 Habitat Conservation Division \\ Pacific Islands Regional Office \\ National Marine Fisheries Service, NOAA \\ 1845 Wasp Boulevard, Building 176 \\ Honolulu, Hawaii 96818
}

Coral reef fishing is an important activity for the social and economic welfare of many coastal communities (Dalzell et al., 1996; Moberg and Folke, 1999). Both commercial and recreational fishing provides jobs, and fishing expenditures generate millions of dollars in sales revenues and value-added benefits to the states and territories of the United States that have coral reefs (Craig, 2008). Healthy fish stocks also support marine recreational activities, such as scuba diving (Parsons and Thur, 2008). Furthermore, in many Pacific islands, coral reef fisheries serve vital nonmarket functions, such as building social and community networks, perpetuating fishing traditions, and providing food for local communities
(Dalzell et al., 1996; Plagányi et al., 2013; Zeller et al., 2015).

Despite their socio-economic importance, reef-associated fisheries have received relatively little attention, especially when compared with pelagic fisheries (Sadovy, 2005), and comprehensive data for reef fisheries are often lacking (Warren-Rhodes et al., 2003; Houk et al., 2012). Furthermore, reef fisheries are particularly challenging to assess because they typically are more complex than pelagic fisheries (Dalzell, 1996). Generally, multiple gear types are used in reef fisheries, and each gear type has its own selectivity and targets multiple species, resulting in overlaps in the composition of the landings of reef fisheries (Dalzell, 1996; McClanahan and Cinner, 2008). A global 
comparative study of reef-fish landings and their ecological footprint concluded that $55 \%$ of coral reef fisheries in 49 island countries were unsustainable, on the basis of the difference between actual reef-fish landings and an annual coral reef maximum sustainable yield value of 5 metric tons (t) $/ \mathrm{km}^{2}$ (Newton et al., 2007). A more recent study in just the western Pacific Ocean found a decline in catches of artisanal fisheries in most Pacific countries (Zeller et al., 2015). The potential, and evidently current, widespread overexploitation of reef fisheries highlights the need for proper management of these resources.

We focused our study on trends in catch and effort of the reef-fish fishery of Guam, which is the largest island in Micronesia and the most southerly island of the Mariana Archipelago in the western Pacific Ocean. As in many other Pacific islands, fish have been important sources of food since the first human settlements (Hensley and Sherwood, 1993). From prehistoric to recent times, there have been at least 52 different fishing methods used on Guam (Kerr'), and some of these traditional practices, such as the seasonal harvest of bigeye scad (Selar crumenopthalmus), fishing with surround nets, and throw- or cast-net fishing, are all still in use (Hensley and Sherwood, 1993). Modern fishing of reef fishes on Guam is best considered a recreational or subsistence fishery, and pelagic fisheries dominate the commercial landings there (Allen and Bartram ${ }^{2}$ ). A study of households (van Beukering et al. ${ }^{3}$ ) conducted in 2007 reported that $35-45 \%$ of respondents were active fishermen and that $28 \%$ of the fish consumed were caught by family members or friends (the 400 respondents in this study included the main ethnic and socioeconomic groups in Guam). Fish make up an especially important source of food for large cultural events, such as baptisms, weddings, and village fiestas (Pinhey et al., 2006).

Apart from their cultural and socioeconomic significance, reef-fish populations can play an important role in enhancing the resilience of reef ecosystems (i.e., the capacity of reef ecosystems to sustain and recover from a human-induced disturbance). For example, abundant and diverse assemblages of herbivorous fishes are effective at reducing algal biomass and at opening up space for settlement of coral recruits (McClanahan, 1997; Mumby et al., 2007a; Mumby and Harborne, 2010; Graham et al., 2011, 2013; Mumby et al., 2013).

Unlike many other countries and territories with coral reefs, Guam has long-term ( $>50$ years) data for its coral reef fishery that have been obtained from creel

\footnotetext{
${ }^{1}$ Kerr, A. M. 2011. Fishing methods of the Mariana Islands, Micronesia. Univ. Guam Mar. Lab. Tech. Rep. 132, 44 p. [Available at website.]

2 Allen, S., and P. Bartram. 2008. Guam as a fishing community. NOAA Pacific Islands Fish. Sci. Cent. Admin. Rep. H-08-01, 61 p. [Available at website.]

${ }^{3}$ van Beukering, P. (ed.), W. Haider, M. Longland, H. Cesar, J. Sablan, S. Shjegstad, B. Beardmore, Y. Liu, G. O. Garces. 2007. The economic value of Guam's coral reefs. Univ. Guam Mar. Lab. Tech. Rep. 116, 102 p. [Available at website.]
}

surveys conducted by the Division of Aquatic and Wildlife Resources (DAWR), Guam Department of Agriculture. This creel survey program provides information on overall harvest and catch per unit of effort (CPUE). In the mid-1980s, DAWR adapted their existing creel survey program to better reflect changes in fishing practices. This survey program now encompasses an offshore boat-based fishery and an inshore shore-based fishery. The boat-based fishery focuses mainly on trolling for pelagic species and bottom fishing for species of commercial value in deepwater (depths $>30 \mathrm{~m}$ ), and the shore-based fishery targets reef fish in shallow-water (depths $\leq 30 \mathrm{~m}$ ) primarily for recreational, subsistence, and cultural reasons (Appendix 1).

Previous analysis of these creel survey data indicated that Guam has a low fishery yield compared with other Pacific islands (Dalzell, 1996). A more recent study concluded that there had been an 86-94\% decline in recreational fish catches over the previous 50 years (Zeller et al., 2007, 2015). Other studies in Guam have documented a similar decreasing trend in both the numbers of fish landed and the mean size at capture (Myers, 1993; McIlwain and Taylor ${ }^{4}$; Lindfield et al., 2014). Hensley and Sherwood (1993) conducted a comprehensive analysis of just the shore-based fishery in Guam from 1982 through 1991. Their main conclusions were that the fishery had changed because of the implementation of more modern fishing techniques and a switch from a traditional economic system (barter, catch what you eat) to a more western one (dollar based, sell for profit) and that these changes led to more pressure on reef resources and to overharvesting the most frequently targeted species.

The perception that reef-fish stocks in Guam are depleted has been corroborated by a recent large-scale study based on visual-survey data; this study concluded that reef-fish biomass around Guam was $66 \%$ below what would be expected in the absence of human perturbations (Williams et al., 2015). Other studies with visual-survey data have noted the relative scarcity of large-bodied fishes around Guam and other populated islands in the Mariana Archipelago, compared with the lightly or unpopulated islands in this archipelago (Richards et al., 2011; Williams et al., 2011). A paucity of large fishes often is indicative of overfishing (Friedlander and DeMartini, 2002; Fenner, 2014).

Although these studies reflect the declining trend in catch and a depletion of the reef-fish biomass at Guam and provide evidence of the effects of fishing on the life history of some taxa (e.g., parrotfishes [Chlorurus spp., Scarus spp.]; Taylor and Choat, 2014), time series for the total biomass of reef-fish populations and changes in the composition of reef-fish catches have not been

\footnotetext{
${ }^{4}$ McIlwain, J. L., and B. M. Taylor. 2009. Parrotfish population dynamics from the Marianas Islands, with a description of the demographic and reproductive characteristics of Chlorurus sordidus: final report to the Western Pacific Regional Fishery Management Council, 61 p. Univ. Guam Mar. Lab., Mangilao, Guam. [Available at website]
} 
quantified. These potential declines in fish populations reduce overall biomass, reproductive potential, and ecosystem function (Taylor et al., 2012; Mumby et al, 2013; Williams et al., 2015). We aimed to improve our understanding of the effects of this socially and culturally important fishery, using the shore-based creel data 1) to compare catch composition in the early years (1985-2000) with the composition in the recent years (2007-2012) and 2) to reconstruct trends in the population biomass of functional groups of reef-fish species over the period 1985-2012 by using recent visual-survey data as a relative index.

\section{Materials and methods}

\section{Fishery data source: creel surveys}

The creel surveys conducted around Guam by the DAWR included 2 distinct fisheries: the shore-based fishery and the boat-based fishery. This division of the data and the terms used to describe its 2 parts are widely used in Guam, including among fishery management agencies; therefore, we used them in our study. It is important to note that the shore-based fishery includes fishing from boats when boats are launched from shore (Appendix 1). The shore-based fishery differs from the boat-based fishery in several key aspects. In general, larger boats are used in the boat-based fishery, which primarily targets pelagic or bottomfish species, and predominantly is a commercial fishery. However, the boat-based fishery landings also include a substantial amount of reef fishes (Appendix 1). We chose not to include boat-based fishery results in our study for 2 reasons. First, boat-based fishing effort is recorded in trip hours, and shore-based fishing effort is recorded in gear hours; therefore, it was difficult to generate CPUE for just the fishing of reef fishes with the boat-based fishery to include in our analysis (Appendix 1 Figure 1). Second, trends in the catch from spearfishing in the boat- and shore-based fisheries are very consistent, indicating that, at least for reef-fish species, these trends reflect changes that are common among the targeted stocks (Appendix 1 Figure 2).

\section{Categorization of species into functional groups}

We analyzed records in the catch database of the shorebased component of the creel survey program for Guam (DAWR data obtained from a database maintained by the Western Pacific Fisheries Information Network [WPacFIN ${ }^{5}$ ], NOAA Pacific Islands Fisheries Science Center [PIFSC]). A total of 580 species or families appeared in the records. For some taxa, there were very little data; therefore, we grouped data of all taxa on the

\footnotetext{
${ }^{5}$ WPacFIN (Western Pacific Fishery Information Network). 2013. Guam shore-based creel survey. NOAA Pacific Islands Fish. Sci. Cent., Honolulu, HI. [Metadata available at website.]
}

basis of their taxonomy, ecological function, and importance to fisheries, as shown in Table 1.

\section{Collection of catch and effort data}

The shore-based surveys of the DAWR creel survey program are designed to collect information on effort and catch for all shore-based fishing activities (Hensley and Sherwood, 1993; Zeller et al., 2007). There are 2 parts in the shore-based fishery: 1) visual surveys to establish the number of people participating in fishing activities (which are called participation surveys) and to collect data on the type of fishing activities observed (effort data) and 2) interviews of a sample of fishermen to collect data on the duration of fishing activities and numbers and sizes of fish caught (catch and effort data). Effort was recorded as hours fished per gear type (gear hour) and catch was recorded as the number and weights of fish caught per hour fished per gear type (Oram et al. ${ }^{6}$ ). Data from restricted areas (Appendix 2) were collected during aerial surveys conducted on the same 2 days that the participation surveys took place (Oram et al.6).

Catch values for the shore-based fishery are provided on a voluntary basis by fishermen to creel surveyors. Effort primarily is based on the visual surveys of fisherman participating in fishing activities, with details about the actual hours of fishing coming from interviews. When conducting surveys, DAWR staff attempt to interview fishermen for each type of gear observed during the participation surveys (Appendix 3 Table 1). However, interviewers are not always able to collect information on all types of gear. For example, since 2005, many spear fishermen have refused to participate in the creel surveys (Lindfield et al., 2014). Consequently, the number of snorkel-spear interviews has declined from an average of 30 per year in 1985-90 to an average below 8 interviews per year during 2007-2012 (Appendix 3 Table 1), and this decline is unfortunate because counts of observations made during participation surveys indicate that spearfishing represents one of the most used fishing method of the shore-based fishery in terms of effort $\left(\mathrm{Bak}^{7}\right)$. Because collecting data on CPUE for most of the taxa and for most of the gears was difficult and infrequent, results dependent on the CPUE statistics were grouped at the family taxon level and are best considered as relative measures.

\section{Estimates of total catch, total effort, and catch per unit of effort}

The staff of the PIFSC program WPacFIN who collaborates with the DAWR, use an expansion algorithm

\footnotetext{
${ }^{6}$ Oram, R., T. Flores Jr., B. Tibbatts, J. Gutierrez, J. P. Gesner, S. Wusstig, A. Regis, D. Hamm, M. Quach, and P. Tao. In press. Guam shore-based creel survey. NOAA Pac. Islands Fish. Sci. Cent. Admin. Rep., 25 p.

${ }^{7}$ Bak, S. 2012. Evaluation of creel survey program in the western Pacific region (Guam, CNMI, and American Samoa), 58 p. Unpubl. report prepared for the Western Pacific Regional Fishery Management Council, Honolulu, HI 96813.
} 


\section{Table 1}

Categorization of functional groups, based on taxonomy, ecological function, or importance to fisheries, used in our study of trends of fish biomass in data from shore-based creel surveys conducted around Guam during 1985-2012

\begin{tabular}{ll}
\hline Functional group name & \multicolumn{1}{c}{ Description and notes } \\
\hline Bait fishes & $\begin{array}{l}\text { Sardine-like species that periodically come to } \\
\text { nearshore waters in large numbers }\end{array}$ \\
Invertebrates & $\begin{array}{l}\text { The top shell (Tectus niloticus) was the domi- } \\
\text { nant component in the total catch of inverte- } \\
\text { brates as a result of very high landings of this } \\
\text { single species of } 30 \mathrm{t} \text { in } 1985 \text { and } 16 \mathrm{t} \text { in } 1991\end{array}$
\end{tabular}

Nonreef-fish species

Macroalgae Planktivores

Coral-consuming fishes

\section{Detritivores}

Invertebrate-consuming fishes

Herbivore-browsers

Species that are pelagic, deepwater, freshwater, or associated with sandy bottoms

Fish species that feed on particles from water column

Fish species that feed primarily on corals

Fish species that feed primarily on detritus

Fish species that feed on invertebrates, separated into exploited species and lightly or nonexploited species

Fish species that browse on plants, separated into exploited species and lightly or nonexploited species

Herbivore-grazers

Herbivore-scrapers

Herbivore-excavators

Humphead parrotfish

Humphead wrasse

Benthic piscivores

Mid-water piscivores

Roving piscivores

Rays

Sharks
Fish species that graze on plants, separated into exploited species and lightly or non-exploited species

Fish species that feed on plants and scrape hard substrate (including corals); all exploited species

Fish species that feed on plants and excavate hard substrate (including corals); all exploited species

An exploited species

An exploited species

Fish species that feed primarily on other fishes and are mostly resident to a reef area separated into exploited species and lightly or nonexploited species

Fish species that feed primarily on other fishes and are benthopelagic, all exploited species

Fish that feed primarily on other fishes and rove on reefs; all exploited species

All exploited species

All exploited species
Selar crumenophthalmus, Ellochelon vaigiensis, Gerres longirostris, Crenimugil crenilabis

Crabs, lobsters, sea cucumbers, mollusks, octopuses, urchins, and clams

Tuna, deepwater snappers (e.g., Etelis coruscans), Kuhlia rupestris

Soldierfishes (Holocentridae), some unicornfishes (e.g., Naso annulatus), chromises (Chromis spp.), cardinalfishes (Apogon spp.)

Mostly butterflyfishes (Chaetodon spp.)

Surgeonfishes (Ctenochaetus spp.)

Exploited: emperors (Lethrinus spp.), snappers (Lutjanus spp.), goatfishes (Mullidae), wrasses (Cheilinus spp.); lightly or nonexploited: porcupinefishes (Diodon spp.), filefishes (Aluterus spp.)

Exploited: sea chubs (Kyphosus spp.), rabbitfishes (Siganus spp.), unicornfishes (e.g., Naso unicornis); lightly or nonexploited: milkfish (Chanos chanos)

Exploited: surgeonfishes (Acanthurus spp.); lightly or nonexploited: sergeants (Abudefduf spp.)

Small-bodied parrotfishes (e.g., most species of Scarus, Chlorurus sordidus)

Large-bodied parrotfishes (e.g., most species of Chlorurus, Scarus rubroviolaceus)

\section{Bolbometopon muricatum}

\section{Cheilinus undulates}

Exploited: groupers (Epinephelus spp.); lightly or nonexploited: morays (Gymnothorax spp.)

Leatherjacket (Scomberoides sp.), needlefishes (Belonidae), reef cornetfish (Fistularia commersonii)

Jacks (Carangidae), barracudas (Sphyraena spp.)

Stingrays (Myliobatiformes)

Reef-associated sharks (e.g., blacktip reef shark [Carcharhinus melanopterus], grey reef shark [C. amblyrhynchos], and whitetip reef shark [Triaenodon obesus]) 
to extrapolate results of the interviews of a sample of fishermen from shore-based surveys to estimates of island-wide catch and effort $\left(\mathrm{Bak}^{7}\right)$. For comparisons of the fishery characteristics of the late 1980s with those of recent years, we used these WPacFIN estimates of aggregate effort and catch to examine possible shifts in fishing activities and catch composition. We somewhat arbitrarily chose to pool across 6-year periods to represent the early and recent periods of fishery data. It was important to pool across multiple years to increase the amount of data available, especially for the recent period (2007-2012); data were pooled also because of large interannual variability.

\section{Fishery-independent surveys: calculation of biomass}

In 2011, scientists of the Coral Reef Ecosystem Program of the NOAA Pacific Islands Fisheries Science Center conducted an intensive, short-term stationary-pointcount survey (133 sample sites) of shallow (depths $\leq 30$ $\mathrm{m}$ ), hard-bottom coral reef areas around Guam. The methods used in this survey are described in detail in Williams et al. (2012) and briefly outlined here. Data of fish abundance and size distribution came from random visual surveys stratified into 3 depth ranges $(<6$ $\mathrm{m}, 6-18 \mathrm{~m}$, and $18-30 \mathrm{~m})$. Because roving apex predators, such as sharks (Carcharhinidae) and jacks (Carangidae), are generally not well sampled by divers in small-area surveys, information on abundance and size distribution of species of roving apex predators came from broad-scale towed-diver surveys conducted around Guam in 2007, 2009, and 2011 by the Coral Reef Ecosystem Program (Richards et al., 2011).

Length estimates of fishes from visual censuses were converted to weight by using allometric lengthweight conversion:

$$
W=a^{*} T L^{b},
$$

where $a$ and $b=$ constants;

$$
T L=\text { total length in millimeters; and }
$$$$
W=\text { wet weight in grams. }
$$

Length-weight parameters came from Taylor, ${ }^{8}$ Taylor et al. (2012), Taylor and Choat (2014), FishBase (Froese and Pauly ${ }^{9}$ ), and Nadon et al. (2015). In cases where length-weight information did not exist for a given species, parameters from congeners were used.

For each taxon, trophic classification was based on diet information, largely from FishBase. Using biomass density from the diver surveys and known areas of habitat from GIS maps, which were adapted within the Coral Reef Ecosystem Program from other GIS products $\left(\mathrm{NCCOS}^{10}\right)$, we estimated biomass per functional

\footnotetext{
8 Taylor, B. 2012. Personal commun. James Cook University, Townsville, Queensland 4811, Australia.

${ }^{9}$ Froese, R., and D. Pauly (eds.). 2015. FishBase, vers. 10/2015. [World Wide Web electronic publication; available at website, accessed March 2015.]

${ }^{10}$ NCCOS (National Centers for Coastal Ocean Science). 2005. National Centers for Coastal Ocean Science, Shallow-
}

group and for all fishes combined; these estimates were minimum values because cryptic and nocturnal fishes generally are undercounted by daytime visual surveys.

\section{Estimation of catchability and reconstruction of historical fish biomass}

A reconstructed time series of reef-fish biomass can be estimated from a CPUE time series and gear-specific catchability coefficients (Haddon, 2001). Generally, it is assumed that catch rates are linearly related to stock biomass and that the catchability coefficient is constant (Haddon, 2001). For the reconstruction in our study, we estimated the relationship between CPUE (as a proxy for relative biomass) and fish population biomass by incorporating a fishery-independent estimate of biomass in 2011, as described in the previous section. This approach requires that the CPUE data come from a representative sample, where the catch was taken in a consistent way by one or more fishing methods. The CPUE data used in this study had limitations, namely that the CPUE data for taxa infrequently encountered by any gear type in the DAWR creel surveys were not reliable; infrequently encountered taxa included many reef fishes, although the CPUE data have been shown to be reliable for some of the jacks (Bak Hospital $^{11}$ ). Because of these limitations, in addressing federal management by means of annual catch limits, the CPUE time series available from the creel surveys were rejected for reef-fish stock assessments (Sabater and Kleiber, 2014). However, in this study, we were interested not in absolute abundance or stock size but in temporal trends of fish populations and relative differences between the late 1980s and recent years, and these data are suitable for that purpose.

In the shore-based surveys, 9 gear types were differentiated (Table 2). The gear type hooks-and-gaffs was used almost entirely to catch octopus (98\% of hook-and-gaff landings for the period 1985-2012), and the type other methods included gears used in gleaning for invertebrates and algae $(60 \%$ and $16 \%$ of total landings per respective gear type; WPacFIN ${ }^{5}$ ) (Hensley and Sherwood, 1993). Therefore, for the historical reconstruction of reef-fish biomass, we excluded catch and effort data for the gear types hooks-and-gaffs and other methods from analyses. We also excluded catch and effort data for the gear type cast nets from estimation of reconstructed reef-fish biomass because cast nets were used primarily to catch juvenile fishes (i.e., rabbitfishes [Siganus spp.], goatfishes [Mullidae], and

Water Benthic Habitats of American Samoa, Guam, and the Commonwealth of the Northern Mariana Islands (CD-ROM). Silver Spring, MD. [Metadata available at website]

${ }^{11}$ Bak Hospital, S. 2015. Western Pacific creel survey program data summary and analysis: Guam, the Commonwealth of the Northern Mariana Islands, and American Samoa. NOAA Pac. Islands Fish. Sci. Cent. Admin. Rep. H15-06C, 194 p. [Available from Pac. Islands Fish. Sci. Cent., Natl. Mar. Fish. Serv., NOAA, 1845 Wasp Blvd., Bldg. 176, Honolulu, HI 96818.] 


\section{Table 2}

Annual mean fishing effort, catch, and catch per unit of effort (CPUE), by gear type, in Guam during the 2 periods 19851990 and 2007-2012. Data were collected during shore-based creel surveys conducted by the Guam Division of Aquatic and Wildlife Resources and expanded by the Western Pacific Fisheries Information Network of the NOAA Pacific Islands Fisheries Science Center. Catch and effort values are based on expanded data and exclude nonreef-associated fishes (e.g., pelagic, freshwater, and intertidal fish species). Values of CPUE (with standard errors [SEs] in parentheses) are based on unexpanded interview data (not on a ratio of tabled catch and effort). $P$-values are from the Welch's 2 -sample $t$-test (which allowed unequal variances), in which CPUE was compared between the 2 time periods. NA represents cases when less than 3 interviews per year per gear type were available (see Appendix 3 Table 1). Effort is given in gear hours (gh), and catch is given in kilograms.

\begin{tabular}{|c|c|c|c|c|c|c|c|}
\hline \multirow[b]{2}{*}{ Gear type } & \multicolumn{3}{|c|}{ 1985-1990 } & \multicolumn{3}{|c|}{ 2007-2012 } & \multirow[b]{2}{*}{$P$-value } \\
\hline & $\begin{array}{c}\text { Mean effort (gh) } \\
(\% \text { of total) }\end{array}$ & $\begin{array}{l}\text { Mean catch } \\
(\mathrm{kg})\end{array}$ & $\begin{array}{l}\text { CPUE (SE) } \\
(\mathrm{kg} / \mathrm{gh})\end{array}$ & $\begin{array}{l}\text { Mean effort (gh) } \\
\quad(\% \text { of total) }\end{array}$ & $\begin{array}{l}\text { Mean catch } \\
\quad(\mathrm{kg})\end{array}$ & $\begin{array}{l}\text { CPUE (SE) } \\
\quad(\mathrm{kg} / \mathrm{gh})\end{array}$ & \\
\hline Hook and line & $127,219(58.5 \%)$ & 22,464 & $0.15(0.02)$ & $145,309(70.6 \%)$ & 17,828 & $0.08(0.02)$ & 0.015 \\
\hline Cast net & $31,913(14.7 \%)$ & 15,88 & $00.36(0.04)$ & $29,555(14.4 \%)$ & 4,108 & $0.10(0.02)$ & $<0.001$ \\
\hline Gill net & $22,647(10.4 \%)$ & 28,259 & $1.25(0.11)$ & $10,918(5.3 \%)$ & 9,807 & $0.56(0.18)$ & 0.01 \\
\hline Surround net & $1470(0.7 \%)$ & 4128 & $1.36(0.67)$ & $552(0.3 \%)$ & 555 & $0.67(0.08)$ & NA \\
\hline Snorkel spear ${ }^{1}$ & $18,453(2.9 \%)$ & 16,507 & $0.76(0.15)$ & $11,736(5.7 \%)$ & 2,137 & $0.19(0.06)$ & 0.013 \\
\hline Scuba spear ${ }^{1}$ & $1553(0.7 \%)$ & 988 & $0.75(0.10)$ & $155(0.1 \%)$ & 58 & $0.34(0.04)$ & NA \\
\hline Hooks and gaffs & $6396(2.9 \%)$ & 2228 & $0.30(0.05)$ & $5554(2.7 \%)$ & 2,139 & $0.36(0.16)$ & NA \\
\hline Drag net & $901(0.4 \%)$ & 1377 & $1.18(0.53)$ & $141(0.1 \%)$ & 133 & $0.97(0.35)$ & NA \\
\hline Other gear & $6868(3.2 \%)$ & 8454 & $0.55(0.29)$ & $1930(0.9 \%)$ & 181 & $0.07(0.01)$ & 0.10 \\
\hline Total & 217,420 & 100,285 & & 205,850 & 36,945 & & \\
\hline
\end{tabular}

${ }^{1}$ Catch and effort values for 2007-2012 are underestimated because most spear fishermen refused to participate in interviews after 2005 (Lindfield et al., 2014).

jacks) that can be hyper-abundant in shallow, sandy bays that were not part of the sampling domain for the fishery-independent visual surveys from which we took data. Appendix 4 shows the number of times each of the exploited fish groups defined in Table 1 were caught by fishermen interviewed for the creel survey program; data were broken out by gear type and pooled into 3-year time periods.

During the interviews for the creel surveys, fishing is reported per region per day type (i.e., weekday or weekend days; for a map of the regions used for creel surveys, see Appendix 2 Figure). Therefore, we first compared annual average CPUE by region and day type, using a Welch 2-sample $t$-test for cases in which we had at least 6 years of CPUE data with at least 3 observations per year (Appendix 3 Table 2). On the basis of the results of these tests (Appendix 5), we decided to aggregate CPUE data over regions and day types for subsequent analyses. Even with such treatment, for some gear types, interview data were sparse, especially for surround net fishing, scuba spearfishing, and drag-net fishing (Appendix 3 Figure). Moreover, for drag-net fishing and scuba spearfishing, some values were missing. We calculated CPUE for missing data as the average of the 3 previous years (Appendix 3 Table 2).

We based our reconstruction of historical relative fish biomass on the assumption that CPUE (I), itself expressed as catch $(C)$ divided by effort $(E)$, is linearly related to biomass $(B)$ in year $t$ :

$$
C_{t} / E_{t}=I_{t}=q * B_{t} .
$$

We further assumed that the gear-specific catchability coefficient $(q)$ was constant. Therefore, although catchability varies depending on the experience of the fisherman and other factors, we assumed that there is no overall change in catchability through time. We also assumed that the observational errors of CPUE were lognormal, were multiplicative, and had constant variance. Although these conditions are unlikely_-given the small extent of actual interview data for many taxa and strata, with the resulting high incidence of zeros and Poisson-like distributions with outliers-these assumptions were adopted to allow a simple approximation. If there are $n$ years in an analysis, the best estimate of the constant $q$ is the geometric average of the time series of ratios of CPUE and biomass $\left(I_{\mathrm{t}} / B_{\mathrm{t}}\right)$, and it can be calculated with the following equation (Haddon, 2001):

$$
q=e^{\frac{1}{n} \sum \operatorname{Ln}\left(\frac{I_{\mathrm{t}}}{B_{\mathrm{t}}}\right)} .
$$

This method is well established for pelagic fisheries (Haddon, 2001), and we further assumed that it is applicable for the complex reef fishery when we parsed out catches and effort by gear type. We used the fisherydependent statistics to estimate CPUE per gear type per year and fishery-independent data to estimate biomass (as detailed previously). However, we had reliable biomass estimates only for 2011. Because we required an $n$ 
of at least 3, we assumed that the mean biomass was the same between 2010 and 2012 and equivalent to that derived from the stationary-point-count surveys conducted in 2011. For each gear type, we derived smoothed estimates of $q$ in accordance with Equation 3, with an $n$ of $3, I$ equal to the gear-specific annual CPUE values for 2010-2012, and $B$ equal to the summed biomass of functional groups exploited by the gear type. Information on which functional groups to include in the summed biomass was derived from the catch composition of total landings for 1985-2012. Functional groups that composed more than $10 \%$ of the catch per gear type were included: for example, over this time span, $23 \%$ of the targeted browsers (e.g., unicornfishes [Naso spp.]), 12\% of the target grazers (most surgeonfishes [Acanthurus spp.]), and $37 \%$ of the roving piscivores (e.g., jacks) were caught by gill-net fishing; therefore, we added the estimates of biomass from the visual surveys for those 3 groups for the calculation of $q$ for gill-net fishing.

To reconstruct the annual total biomass for the period 1985-2012, we divided the gear-specific CPUE for each year by the estimated gear-specific catchability $q$, using Equation 2 rewritten as $B_{\mathrm{t}}=I_{\mathrm{t}} / q$. Within each year, we then calculated the reconstructed biomass for each functional group by multiplying the annual total biomass estimate by the species composition observed in 2011. For example, in 1985, the total biomass was estimated at 10,025 t, and excavators (large-bodied parrotfishes [e.g. Chlorurus spp.]) composed $1.3 \%$ of the species composition in 2011; given those values, the biomass of excavators in 1985 was estimated at 130 $\mathrm{t}(10,025 \times 0.013)$. Therefore, the results of this analysis indicate trends in relative fish stock size over time, with the assumption of constant catchabilities and species composition.

\section{Results}

Past and recent periods: comparing total catch, effort, and catch per unit of effort

Hook-and-line was the most commonly used gear type, accounting for 59\% of total estimated annual effort in 1985-1990 (past) and 71\% of total estimated annual effort in 2007-2012 (recent) (Table 2). Cast nets were the second most often used gear type, accounting for $\sim 14 \%$ of total annual estimated effort in both time periods. Effort for all other gear types was reported less frequently in recent years than during the earlier time period, and declines in effort between the time periods ranged from $16 \%$ for drag net fishing to $87 \%$ for hook-and-gaff fishing (Table 2). The decline in effort for those other gears was balanced by a $14 \%$ increase in effort for hook-and-line fishing, resulting in an estimated total fishing effort that was similar in the 2 time periods: an annual mean of 217,420 gear hours for 1985-1990 in contrast to an annual mean of 205,850 gear hours for 2007-2012.

Reported catch was considerably higher during the period 1985-1990, with an estimated mean annual total catch of $100 \mathrm{t}$, compared with an average of 37 $\mathrm{t}$ in the period 2007-2012 (Fig. 1, Table 2). The most noteworthy difference between the 2 time periods was a $74 \%$ decrease in the catch for cast net fishing despite little change in effort and a $21 \%$ decrease in the catch from hook-and-line fishing despite a $14 \%$ increase in effort. The largest decline in catch was for spearfishing: reported catch of snorkel spearfishing and scuba spearfishing dropped by $87 \%$ and $94 \%$, respectively (with reported effort declining by $36 \%$ and $90 \%$, respectively). However, the observed decline in estimated spearfishing effort and landings is certainly related to the refusal of some spear fishermen to participate in creel surveys since around 2005 (Lindfield et al., 2014).

Based on the total landings for the shore-based fishery and the use of $95 \mathrm{~km}^{2}$ as the reef area at depths of 0-30 $\mathrm{m}$ around Guam (determined with the adapted habitat maps of hard- and soft-bottom habitats), annual yields dropped from $1.30 \mathrm{t} / \mathrm{km}^{2}$ during 1985-1990 to $0.58 \mathrm{t} / \mathrm{km}^{2}$ during 2007-2012. For reef-associated fishes (i.e., excluding pelagic fishes, invertebrates, and nonreef-associated species), annual yield was $1.59 \mathrm{t} / \mathrm{km}^{2}$ and $0.74 \mathrm{t} / \mathrm{km}^{2}$, respectively, and $71 \mathrm{~km}^{2}$ were used as the reef area for hard-bottom habitat at depths of 0-30 $\mathrm{m}$ around Guam (determined with one of the adapted habitat maps).

Hook-and-line fishing was assumed to be the most reliable data source because hook and line gear was the dominant gear type in the catch and effort records. On the basis of the fishery data for this gear type only, landings showed no clear trend over time, albeit with large annual fluctuations (Fig. 2A). However, landings of species other than bait fishes (e.g., bigeye scad [Selar crumenophthalmus]) showed a downward trend (Fig. 2A). The mean annual CPUE, based on the unexpanded interview data, for hook-and-line fishing varied because of the interannual fluctuation in bait fish landings, but the overall mean CPUE decreased $49 \%$ between the 2 time periods, from an annual mean of $0.15 \mathrm{~kg} / \mathrm{gear}$ hour (standard error [SE] 0.02) for 1985-1990 to $0.08 \mathrm{~kg} /$ gear hour (SE 0.02) for 2007-2012 (Table 2, Fig. 2B).

CPUE was also significantly lower in the recent time period for gill net fishing and snorkel spearfishing, compared with levels in the past. The only gear type for which CPUE did not significantly decrease $(P=0.1)$ was the gear type other methods (i.e., reef gleaning), although CPUE for that type trended downward (Table 2 ). For the remaining gear types, there was not enough information to statistically compare differences between the time periods (annual number of interviews was less than 3); however, for all gear types, except hooks-and-gaffs, mean CPUE was lower in the recent time period and the overall trend showed a decline in CPUE (Appendix 3 Figure).

\section{Species composition of landings}

In most years, combined landings of browsers (predominantly unicornfishes and rabbitfishes) and invertebrate 


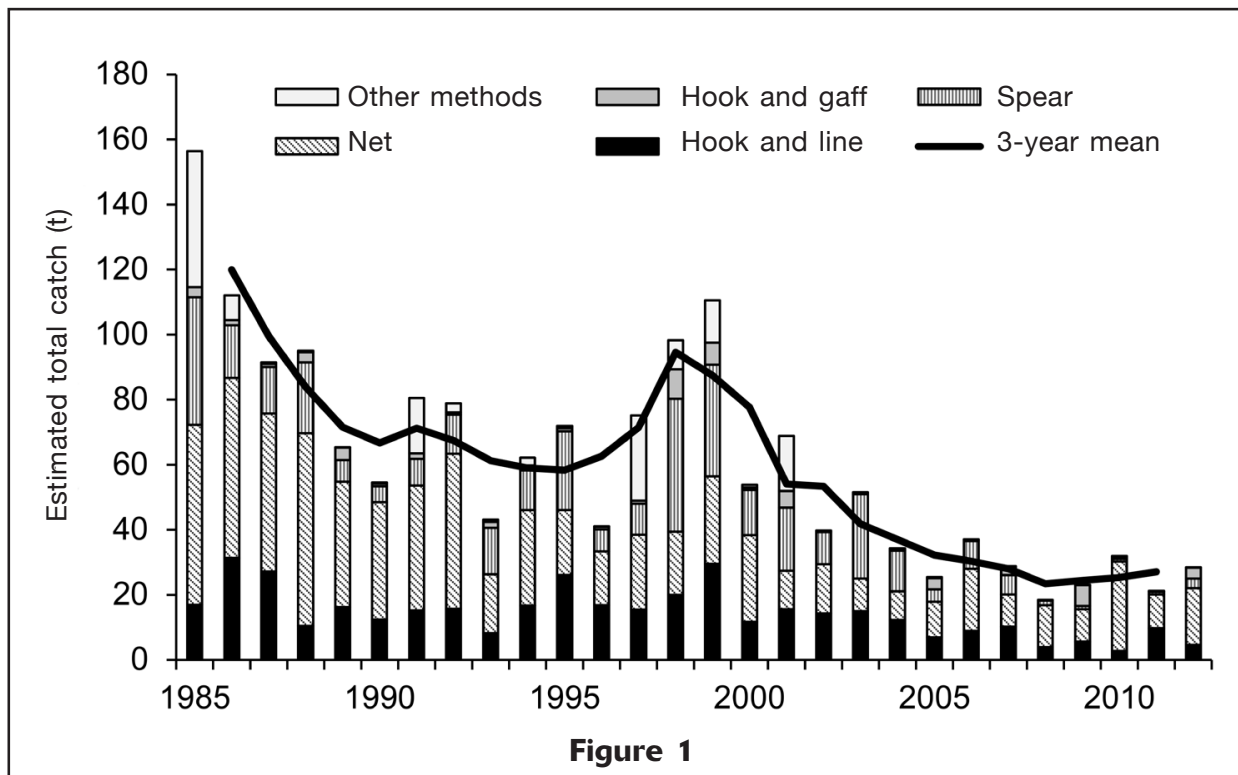

Time series of shore-based fishery landings in Guam for the period 1985-2012 in metric tons ( $\mathrm{t}$ ) per gear type based on expanded data provided by the Western Pacific Fisheries Information Network of the NOAA Pacific Islands Fisheries Science Center. Landings of pelagic bait fishes are excluded from the catches for hook-and-line fishing. Net fishing includes fishing with a cast net, gill net, surround net, and drag net, and spear fishing includes fishing with both scuba and snorkel spear. The gear type of the category "other methods" includes gears used in gleaning invertebrates and algae. The black line represents the 3-year mean of the catches summed over all gear types.
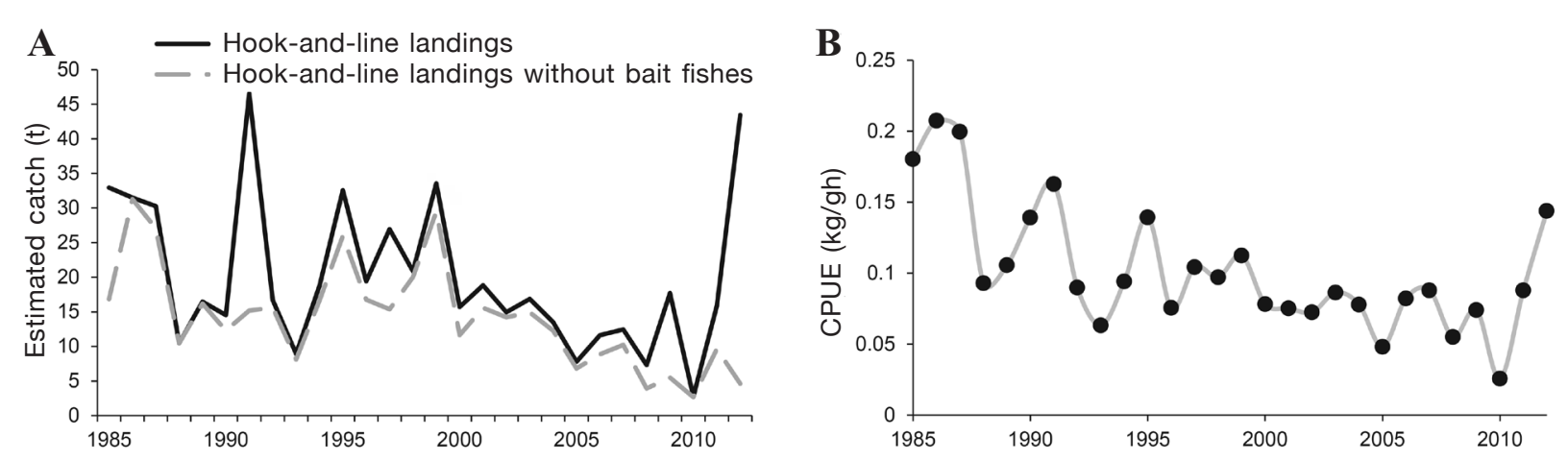

Figure 2

Around Guam for the period 1985-2012, time series (A) of landings for the shore-based hook-and-line fishery based on expanded data provided by the Western Pacific Fisheries Information Network of the NOAA Pacific Islands Fisheries Science Center and (B) of hook-and-line catch per unit of effort (CPUE) based on data from shore-based creel surveys conducted by the Guam Division of Aquatic and Wildlife Resources. Landings of pelagic bait fishes were excluded from data represented by the gray dashed line in graph A. Values of CPUE are given in kilograms per gear hour (gh).

feeders (predominantly goatfishes and emperors [Lethrinus spp.]) made up $>40 \%$ of the total catch (Table $3)$. In comparison with catch data from the late $1980 \mathrm{~s}$, data for 2007-2012 showed a shift from the largest group being target browsers to the largest group being pelagic bait fishes. In general, the relative contribution of bait fishes increased over time, with bait fishes making up as much as $72.6 \%$ of the total catch (in 2012). The humphead parrotfish (Bolbometopon muricatum) was reported only in catches in 1985, and the humphead wrasse (Cheilinus undulatus) was reported in, on average, $0.4 \%$ of the catches during the period $1985-1990$ but dropped to $<0.1 \%$ of catches during the period 2007-2012. Roving piscivores, on the other 


\section{Table 3}

Relative contributions of functional groups to the total catch per year, based on data collected during shore-based creel surveys conducted by the Guam Division of Aquatic and Wildlife Resources and expanded by the Western Pacific Fisheries Information Network of the NOAA Pacific Islands Fisheries Science Center. All values are percentages. Numbers in italic type indicate a contribution $>15 \%$ to the annual total catch. The functional groups are described in Table 1 .

\begin{tabular}{|c|c|c|c|c|c|c|c|c|c|c|c|c|c|c|c|c|}
\hline Functional group & 1985 & 1986 & 1987 & 1988 & 1989 & 1990 & 1991 & 1992 & 1993 & 1994 & 1995 & 1996 & 1997 & 1998 & 1999 & 2000 \\
\hline Bait fishes & 16.4 & 6.8 & 7.2 & 9.1 & 9.8 & 15.8 & 42.2 & 12.0 & 9.9 & 10.1 & 13.9 & 10.7 & 23.6 & 3.7 & 6.5 & 16.5 \\
\hline Invertebrates & 22.0 & 4.4 & 3.1 & 3.6 & 6.8 & 5.1 & 12.2 & 6.0 & 8.9 & 9.2 & 4.8 & 2.8 & 12.8 & 15.4 & 9.2 & 6.1 \\
\hline Nonreef-associated fishes & 1.8 & 5.2 & 7.9 & 2.1 & 0.8 & 1.8 & 0.5 & 1.8 & 2.8 & 2.5 & 1.6 & 0.8 & 2.5 & 5.3 & 2.4 & 2.0 \\
\hline Macroalgae & 3.2 & 3.2 & 0.1 & 0.1 & 0.0 & 0.0 & 0.5 & 0.1 & 0.3 & 0.8 & 0.3 & 0.0 & 11.6 & 3.4 & 6.6 & 0.1 \\
\hline Invertebrate-consuming fishes & 15.1 & 20.3 & 19.7 & 24.1 & 27.4 & 19.0 & 9.5 & 21.8 & 23.8 & 18.4 & 19.8 & 22.6 & 13.8 & 18.9 & 12.5 & 19.5 \\
\hline Planktivorous fishes & 1.9 & 0.7 & 1.1 & 0.7 & 2.2 & 1.5 & 0.6 & 1.2 & 5.2 & 1.8 & 2.2 & 2.5 & 1.4 & 3.0 & 1.1 & 2.0 \\
\hline Coral-consuming fishes & 0.0 & 0.0 & 0.0 & 0.0 & 0.0 & 0.0 & 0.0 & 0.0 & 0.0 & 0.0 & 0.0 & 0.0 & 0.0 & 0.0 & 0.1 & 0.6 \\
\hline Detritivorous fishes & 0.1 & 0.2 & 0.0 & 0.0 & 0.0 & 0.0 & 0.0 & 0.1 & 0.2 & 0.4 & 0.3 & 0.1 & 0.1 & 0.2 & 0.1 & 0.3 \\
\hline Browsers & 22.4 & 30.8 & 39.0 & 40.4 & 34.5 & 26.3 & 16.0 & 35.8 & 17.0 & 29.4 & 35.0 & 36.2 & 19.6 & 30.7 & 29.0 & 30.5 \\
\hline Grazers & 3.9 & 3.9 & 9.3 & 8.8 & 7.7 & 12.3 & 3.9 & 9.6 & 7.4 & 6.3 & 7.6 & 10.6 & 4.4 & 4.4 & 4.4 & 7.8 \\
\hline Scrapers & 1.3 & 1.2 & 0.5 & 1.1 & 0.2 & 0.5 & 2.5 & 1.7 & 2.2 & 2.2 & 1.7 & 1.7 & 1.6 & 1.5 & 4.3 & 1.6 \\
\hline Excavators & 1.8 & 0.0 & 0.0 & 0.2 & 0.0 & 0.5 & 0.9 & 0.9 & 0.8 & 0.7 & 1.6 & 1.0 & 0.4 & 2.7 & 1.2 & 0.8 \\
\hline Humphead parrotfish & 0.2 & 0.0 & 0.0 & 0.0 & 0.0 & 0.0 & 0.0 & 0.0 & 0.0 & 0.0 & 0.0 & 0.0 & 0.0 & 0.0 & 0.0 & 0.0 \\
\hline Humphead wrasse & 0.3 & 0.1 & 0.2 & 0.6 & 1.1 & 0.1 & 0.0 & 0.0 & 0.0 & 0.0 & 0.0 & 0.5 & 0.0 & 0.0 & 0.0 & 0.1 \\
\hline Benthic piscivores & 1.7 & 2.5 & 5.2 & 2.2 & 1.1 & 5.4 & 2.6 & 3.2 & 8.1 & 4.5 & 4.5 & 2.3 & 2.4 & 4.0 & 4.4 & 5.4 \\
\hline Mid-water piscivores & 3.0 & 3.0 & 0.0 & 1.6 & 3.0 & 2.8 & 1.6 & 1.1 & 2.2 & 3.2 & 2.1 & 2.2 & 0.2 & 0.5 & 3.4 & 1.3 \\
\hline Roving piscivores & 4.7 & 3.3 & 6.8 & 5.2 & 4.8 & 8.9 & 7.1 & 4.3 & 9.6 & 3.6 & 3.3 & 5.9 & 5.4 & 6.0 & 10.5 & 5.4 \\
\hline Rays & 0.0 & 0.1 & 0.0 & 0.2 & 0.4 & 0.0 & 0.0 & 0.0 & 0.0 & 0.0 & 0.0 & 0.0 & 0.0 & 0.1 & 0.0 & 0.0 \\
\hline \multirow[t]{2}{*}{ Sharks } & 0.0 & 14.2 & 0.0 & 0.0 & 0.0 & 0.0 & 0.0 & 0.4 & 1.6 & 7.0 & 1.4 & 0.1 & 0.4 & 0.2 & 4.2 & 0.1 \\
\hline & 2001 & 2002 & 2003 & 2004 & 42005 & 2006 & 2007 & 2008 & 2009 & 2010 & 2011 & 2012 & & & & \\
\hline Bait fishes & 8.3 & 5.5 & 5.9 & 6.0 & 10.7 & 11.2 & 10.4 & 21.1 & 47.5 & 3.4 & 30.1 & 72.6 & & & & \\
\hline Invertebrates & 17.4 & 3.8 & 14.4 & 6.9 & 20.1 & 5.5 & 7.8 & 2.2 & 13.7 & 2.9 & 1.0 & 4.8 & & & & \\
\hline Nonreef-associated fishes & 1.9 & 1.2 & 5.5 & 13.1 & 3.5 & 2.2 & 0.4 & 2.3 & 2.6 & 5.0 & 0.6 & 2.8 & & & & \\
\hline Macroalgae & 10.3 & 0.3 & 0.2 & 0.1 & 0.0 & 0.1 & 0.1 & 0.1 & 0.1 & 0.3 & 0.1 & 0.0 & & & & \\
\hline Invertebrate-consuming fishes & 19.7 & 20.8 & 17.8 & 10.0 & 20.5 & 10.8 & 16.2 & 7.9 & 6.5 & 10.2 & 15.3 & 6.1 & & & & \\
\hline Planktivorous fishes & 0.8 & 1.0 & 0.9 & 3.2 & 0.5 & 0.7 & 0.3 & 0.6 & 1.4 & 1.0 & 0.2 & 0.2 & & & & \\
\hline Coral-consuming fishes & 0.2 & 0.0 & 0.0 & 0.0 & 0.0 & 0.0 & 0.0 & 0.1 & 0.0 & 0.0 & 0.0 & 3.9 & & & & \\
\hline Detritivores & 2.2 & 0.0 & 0.0 & 0.0 & 0.1 & 0.3 & 2.7 & 0.0 & 0.0 & 0.0 & 0.0 & 0.0 & & & & \\
\hline Browsers & 16.8 & 35.0 & 26.1 & 22.4 & 12.1 & 35.9 & 25.7 & 21.1 & 7.4 & 46.1 & 10.3 & 2.9 & & & & \\
\hline Grazers & 5.1 & 5.6 & 10.3 & 9.8 & 8.2 & 8.4 & 5.5 & 8.7 & 6.9 & 20.3 & 6.8 & 0.3 & & & & \\
\hline Scrapers & 0.6 & 1.1 & 3.4 & 0.9 & 2.1 & 2.6 & 0.9 & 4.8 & 0.6 & 1.3 & 1.7 & 0.5 & & & & \\
\hline Excavators & 0.7 & 1.0 & 3.5 & 1.4 & 0.5 & 0.3 & 0.1 & 0.4 & 0.2 & 0.1 & 0.6 & 0.0 & & & & \\
\hline Humphead parrotfish & 0.0 & 0.0 & 0.0 & 0.0 & 0.0 & 0.0 & 0.0 & 0.0 & 0.0 & 0.0 & 0.0 & 0.0 & & & & \\
\hline Humphead wrasse & 0.0 & 0.0 & 0.2 & 0.0 & 0.0 & 0.1 & 0.4 & 0.0 & 0.0 & 0.0 & 0.0 & 0.1 & & & & \\
\hline Benthic piscivores & 2.3 & 6.1 & 3.1 & 4.0 & 3.5 & 5.4 & 6.4 & 2.2 & 1.2 & 0.5 & 0.8 & 0.5 & & & & \\
\hline Mid-water piscivores & 2.9 & 1.3 & 1.0 & 2.8 & 0.8 & 0.9 & 0.2 & 1.8 & 0.6 & 0.9 & 1.6 & 0.0 & & & & \\
\hline Roving piscivores & 10.1 & 13.6 & 6.0 & 19.4 & 17.2 & 9.2 & 22.9 & 24.2 & 11.3 & 8.1 & 30.9 & 5.2 & & & & \\
\hline Rays & 0.0 & 0.0 & 0.0 & 0.0 & 0.0 & 2.0 & 0.0 & 0.0 & 0.0 & 0.0 & 0.0 & 0.0 & & & & \\
\hline Sharks & 0.7 & 3.5 & 1.8 & 0.0 & 0.3 & 4.3 & 0.1 & 2.4 & 0.0 & 0.0 & 0.0 & 0.0 & & & & \\
\hline
\end{tabular}

hand, increased on average from $5.6 \%$ to $17.1 \%$ of the catch over the same time periods. The available data do not include information on fish size; therefore, it is not clear whether this increase was a result of increases in the seasonal fishery for juvenile jacks or in catches of mature jacks. However, because the gear types that target juveniles-hook-and-line and cast net-had increased catches and because catches by gill net, which does not target juvenile jacks, dropped by half, it appears that the increase in catch of roving piscivores was likely due to an increased catch of juveniles.

\section{Reconstruction of fish biomass by functional group}

Results from initial analysis of unexpanded data, from the interviews as part of the shore-based surveys, indicate that only for the CPUE for hook-and-line fishing in regions 1 and 2 on the eastern coast of Guam (for a map of the regions used in creel surveys, see Appendix 2 Figure) was there a difference $(P<0.05)$ between day types (weekdays and weekend days), and there was no significant difference in CPUE between regions (Appendix 5). Therefore, to simplify analysis, we pooled 


\section{Table 4}

Mean catch per unit of effort (CPUE), by gear type, determined from shore-based creel surveys conducted by the Guam Division of Aquatic and Wildlife Resources in 2010-2012 and estimated biomass of targeted species, by gear type, from visual surveys conducted by the Coral Reef Ecosystem Program of the NOAA Pacific Islands Fisheries Science Center in 2011. These values were used to calculate the catchability coefficient $(q)$ for each gear type. Data for cast-net fishing were excluded from this analysis (see the Materials and methods section). gh=gear hour.

\begin{tabular}{|c|c|c|c|c|c|}
\hline \multirow[b]{2}{*}{ Gear type } & \multicolumn{3}{|c|}{ CPUE (kg/gh) } & \multirow{2}{*}{$\begin{array}{c}\text { Biomass } \\
\text { (t) }\end{array}$} & \multirow{2}{*}{ (/1000 gh) } \\
\hline & 2010 & 2011 & 2012 & & \\
\hline Drag net & 0.99 & 0.91 & 0.31 & 157 & 0.0042 \\
\hline Gill net & 1.26 & 0.09 & 0.77 & 386 & 0.0012 \\
\hline Hook and line & 0.03 & 0.09 & 0.14 & 324 & 0.0002 \\
\hline Scuba spear & 0.37 & 0.40 & 0.24 & 544 & 0.0006 \\
\hline Snorkel spear & 0.06 & 0.06 & 0.38 & 386 & 0.0003 \\
\hline
\end{tabular}

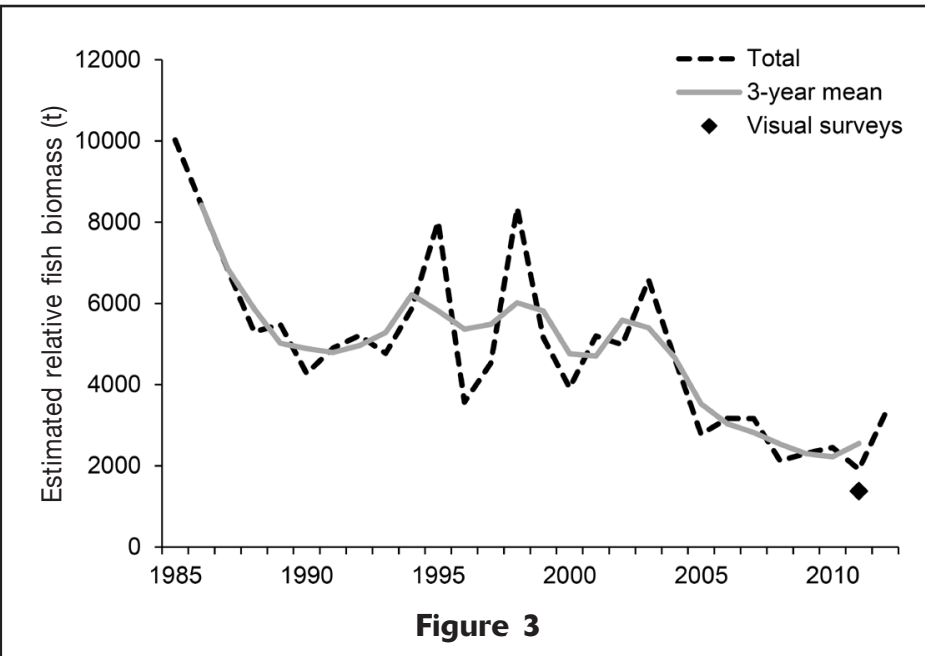

Reconstructed time series of total biomass of reef fishes in shore-based creel surveys conducted around Guam in 1985-2012 in relation to the estimate of total biomass from visual surveys conducted in 2011. The time series excludes pelagic species and bai tfishes and is based on annual catch composition per gear type with the assumption of a constant catchability coefficient for each gear type. The black diamond represents the estimated biomass for 2011 computed by multiplying biomass density (from surveys conducted by the Coral Reef Ecosystem Program of the NOAA Pacific Islands Fisheries Science Center) by the reef area $\left(71 \mathrm{~km}^{2}\right)$ of hard-bottom habitats at depths of $0-30 \mathrm{~m}$ around Guam. The gray line indicates the 3-year mean of catches summed over all gear types.

the data up to the island level by combining both day types and all regions. With the estimated catchability coefficient of each gear type (Table 4), we reconstructed a time series for relative biomass (Fig. 3). There was a steep (almost 50\%) downward trend in fish biomass from 1985 to around 1990. In the following decade, fish biomass leveled off but then declined again by about 2003 (Fig. 3).

On the basis of the reconstructed time series for total fish biomass (Fig. 3), we were able to estimate relative biomass of the functional groups targeted in the shore-based fisheries for reef fishes (Fig. 4). For the reconstructed biomass per functional group, species composition was assumed to have remained similar to the species composition observed during the visual surveys conducted in 2011 and, therefore, is an estimate of the true value.

\section{Discussion}

The fishery data used in this study show an overall reduction in catches in Guam that in turn indicates a general decline in reconstructed stock biomass from the late 1980 s to recent years (Fig. 3) -a finding that is consistent with the results of fishery-independent surveys that show significant depletion of shallow-water reef-fish populations and large fishes around Guam (Richards et al., 2011; Williams et al., 2011, 2015). Parrotfishes were caught by hook-and-line fishing (33\%) and by spearfishing (40\%), and lower landings were reported in recent years. Assuming there have been no increases in recruitment and that the size composition of the catch reflects the size structure of the population, this decline in catches indicates a reduction in adult biomass and reproductive potential of the stock (Birkeland and Dayton, 2005). The decline in reconstructed biomass of parrotfishes and other herbivores (Fig. 4) observed in our study is also of some ecological concern. Herbivorous fishes play a critical role in maintaining benthic algal communities in states that are conducive for coral growth and recruitment (Mumby et al., 2007a; McClanahan, 1997), and herbivory is particularly important in promoting coral recovery after disturbances, such as hurricanes and bleaching events (Mumby et al., 2007b; Edwards et al., 2011; Graham et al., 2013). Therefore, declines in local parrotfish biomass may indicate that reefs surrounding Guam are less resilient to such events.

Estimated CPUE and catches for all gear types were substantially lower during the recent period (2007-2012) than they were during the period 1985-1990 (Table 2). Because CPUE estimates for the hook-and-line fishery in our earliest period ( $0.15 \mathrm{~kg} / \mathrm{gear}$ hour for 1985-1990; Table 2) are considerably lower than the estimates recorded in Guam during the early $1980 \mathrm{~s}(0.55 \mathrm{~kg} /$ gear hour; Katnik, 1982, cited in Dalzell et al., 1996), it seems likely that the evident downward trends in 
CPUE and catch began before the first period for which we have creel data (before 1985). Fishery yields of reef fishes around Guam also have been low compared with previously published global yields for coral reef fisheries-annual levels that ranged from 0.2 to 44.0 $\mathrm{t} / \mathrm{km}^{2}$ (Dalzell, 1996). These global values are, however, confounded by differences in species groupings and effort reported for different locations around the world, as well as by the different assumptions about habitats included in area calculations. Still, our results clearly show that the downward trend in catch and CPUE, a pattern that earlier studies already noted (Hensley and Sherwood, 1993; Myers, 1993), has continued, and another study has reported that declines in catch started at least 50 years ago (Zeller et al., 2015).

Declines in catch are not restricted to Guam. A recent synthesis of domestic catch reconstruction for 25 Pacific island countries and territories from 1950 to 2010 showed that, at $60 \%$ of those localities, peak catch occurred before 2000 and that in only one location did the peak catch occur after 2010 (Zeller et al., 2015). Also noteworthy is the shift in catch composition, where the majority of the landings in recent years comprises lower-valued species, such as the bigeye scad (Selar crumenophthalmus). This change in catch composition could be a result of the large pulses in bait fish populations, but it could also indicate a change in composition of the fish community. A similar change in catch composition was found in an analysis of landings by spear fishermen (Lindfield et al., 2014). Scuba spearfishing around Guam was associated not only with a decline in the size of parrotfishes caught but also with a shift from a dominance of large parrotfishes to a mixed assemblage with increasing proportions of surgeonfishes. This shift in community structure and a possible loss in biodiversity could lead to altered ecosystem functioning. Shifts in community structure and an altered ecosystem functioning have been observed in Kiritimati, where, in comparison with an unfished location (Palmyra Atoll), apex predators were relatively smaller, had a shorter life span, and were less abundant and prey fishes were larger but not more abundant (Ruttenberg et al., 2011). In a global analysis of reef fish surveys, Mora et al. (2011) found a strong link between ecosystem functioning and biodiversity, the latter of which is negatively influenced by human populations through overexploitation or the loss or degradation of habitats. Effective efforts to con- serve biodiversity should, therefore, include the preservation of the functional roles that species perform (Brown and Mumby, 2014).

Although we are confident that our results provide a good indication of trends in CPUE and in the derived relative fish biomass, our study has several limitations. Calculating the CPUE for a multispecies, multigear reef fishery is not straight forward. Among other issues, many factors influence the decisions that fishermen make about when and where to fish and which gear to use. Consequently, there are undocumented changes in selectivity or catchability of specific gear types over different temporal and spatial scales. Accounting for all of these dependent decisions of fishermen was beyond the scope of our study; however, there was no quantitative or anecdotal information that documented any systematic changes in those decisions over the time period for which we have data. Also, too little creel data are available for some gear types, such as cast nets, and for spearfishing, and that lack of data clearly limits the scope by which the WPacFIN-expanded data can fully represent the total catch and effort.

Additionally, the assumption that the species composition has stayed the same between 1985 and 2012 is also unlikely to be true because the catch composition did change. Fishing affects the species composition of piscivores (e.g., sharks and jacks), and large fishes are often the first ones to disappear from catch records (Friedlander and DeMartini, 2002; Fenner, 2014). We 
recognize that it is important to be cautious in interpreting the results of our analysis of data from the creel survey program for Guam. However, the lack of alternative survey or fishery information over extended time periods makes it important that these data are used to their fullest extent.

The findings from our analysis of the data from shore-based creel surveys, given the above caveats, indicate a decline in relative biomass of reef-fish populations and a shift in community structure since the start (1985) of our study period. Our results are broadly in agreement with the findings of a number of previous studies that have focused on catches from boat- and shore-based fisheries in Guam (Hensley and Sherwood, 1993; Myers, 1993; Dalzell, 1996; Zeller et al., 2007, 2015), as well as with results of studies of local fish abundance and size distributions (Richards et al., 2011; Houk et al., 2012; Lindfield et al., 2014). Because fishing for reef fishes is an important social and cultural activity for fishermen and their families in Guam, the decline over recent decades in the biomass of stocks of shallow-water coral reef fishes is a cause for concern.

\section{Acknowledgments}

Funding for the senior author and S. Grafeld was obtained from the NOAA Coral Reef Conservation Program. We would like to acknowledge the staff at the Division of Aquatic and Wildlife Resources, Guam Department of Agriculture, for data collection and the following people at the NOAA Pacific Islands Fisheries Science Center: K. Low, M. Quack, and P. Tao for extracting and helping to interpret data, M. Nadon for advice on data analyses, and C. Boggs and J. Wetherall for their valuable comments on the draft manuscript.

\section{Literature cited}

Birkeland, C., and P. K. Dayton.

2005. The importance in fishery management of leaving the big ones. Trends Ecol. Evol. 20:356-358. Article

Brown, C. J., and P. J. Mumby.

2014. Trade-offs between fisheries and the conservation of ecosystem function are defined by management strategy. Front. Ecol. Environ. 12:324-329. Article

Craig, R. K.

2008. Coral reefs, fishing, and tourism: tensions in U.S. ocean law and policy reform. Stanford Environ. Law J. $27: 3-41$.

Dalzell, P.

1996. Catch rates, selectivity and yields of reef fishing. In Reef fisheries (N. V. C. Polunin and C. M. Roberts, eds.), p. 161-192. Springer Science+Media, Dordrecht, Netherlands.

Dalzell, P., T. J. H. Adams, and N. V. C. Polunin.

1996. Coastal fisheries in the Pacific islands. Oceanogr. Mar. Biol. Annu. Rev. 34:395-531.
Edwards, H. J., I. A. Elliott, C. M. Eakin, A. Irikawa, J. S. Madin, M. McField, J. A. Morgan, R. Van Woesik, and P. J. Mumby.

2011. How much time can herbivore protection buy for coral reefs under realistic regimes of hurricanes and coral bleaching? Global Change Biol. 17:2033-2048. Article

Fenner, D.

2014. Fishing down the largest coral reef fish species. Mar. Poll. Bull. 84:9-16. Article

Friedlander, A. M., and E. E. DeMartini.

2002. Contrasts in density, size, and biomass of reef fishes between the northwestern and the main Hawaiian islands: the effects of fishing down apex predators. Mar. Ecol. Prog. Ser. 230:253-264. Article

Graham, N. A. J., D. R. Bellwood, J. E. Cinner, T. P. Hughes, A. V. Norström, and M. Nyström.

2013. Managing resilience to reverse phase shifts in coral reefs. Front. Ecol. Environ. 11:541-548. Article

Graham, N. A. J., P. Chabanet, R. D. Evans, S. Jennings, Y. Letourneur, M. A. MacNeil, T. R. McClanahan, M. C. Öhman, N. V. C. Polunin, and S. K. Wilson.

2011. Extinction vulnerability of coral reef fishes. Ecol. Lett. 14:341-348. Article

Haddon, M.

2001. Modelling and quantitative methods in fisheries, rev. print., 406 p. Chapman and Hall, Boca Raton, FL.

Hensley, R. A., and T. S. Sherwood.

1993. An overview of Guam's inshore fisheries. Mar. Fish. Rev. 55(2):129-138.

Houk, P., K. Rhodes, J. Cuetos-Bueno, S. Lindfield, V. Fread, and J. L. McIlwain.

2012. Commercial coral-reef fisheries across Micronesia: a need for improving management. Coral Reefs 31:13-26. Article

Lindfield, S. J., J. L. McIlwain, and E. S. Harvey.

2014. Depth refuge and the impacts of SCUBA spearfishing on coral reef fishes. PLoS ONE 9(3):e92628. Article

McClanahan, T. R.

1997. Primary succession of coral-reef algae: differing patters on fished versus unfished reefs. J. Exp. Mar. Biol. Ecol. 218:77-102. Article

McClanahan, T. R., and J. E. Cinner.

2008. A framework for adaptive gear and ecosystem-based management in the artisanal coral reef fishery of Papua New Guinea. Aquat. Conserv.: Mar. Freshw. Ecosyst. 18:493-507. Article

Moberg, F., and C. Folke.

1999. Ecological goods and services of coral reef ecosystems. Ecol. Econ. 29:215-233. Article

Mora, C., O. Aburto-Oropeza, A. A. Bocos, P. M. Ayotte, S. Banks, A. G. Bauman, M. Beger, S. Bessudo, D. J. Booth, E. Brokovich, et al.

2011. Global human footprint on the linkage between biodiversity and ecosystem functioning in reef fishes. PLoS Biol. 9(4):e1000606. Article

Mumby, P. J., S. Bejarano, Y. Golbuu, R. S. Steneck, S. N. Arnold, R. van Woesik, and A. M. Friedlander.

2013. Empirical relationships among resilience indicators on Micronesian reefs. Coral Reefs 32:213-236. Article

Mumby, P. J., and A. R. Harborne.

2010. Marine reserves enhance the recovery of corals on Caribbean reefs. PLoS ONE 5(1):e8657. Article

Mumby, P. J., A. R. Harborne, J. Williams, C. V. Kappel, D. R. Brumbaugh, F. Micheli, K. E. Holmes, C. P. Dahlgren, C. B. Paris, and P. G. Blackwell.

2007a. Trophic cascade facilitates coral recruitment 
in a marine reserve. Proc. Natl. Acad. Sci. U.S.A. 104:8362-8367. Article

Mumby, P. J., A. Hastings, and H. J. Edwards.

2007b. Thresholds and the resilience of Caribbean coral reefs. Nature 450:98-101.

Myers, R. F.

1993. Guam's small-boat-based fisheries. Mar. Fish. Rev. 55(2):117-128.

Nadon, M. O., J. S. Ault, I. D. Williams, S. G. Smith, and G. T. DiNardo.

2015. Length-based assessment of coral reef fish populations in the main and Northwestern Hawaiian Islands. PLoS ONE 10(8):e0133960. Article

Newton, K., I. M. Côté, G. M. Pilling, S. Jennings, and N. K. Dulvy.

2007. Current and future sustainability of island coral reef fisheries. Curr. Biol. 17:655-658. Article

Parsons, G. R., and S. M. Thur.

2008. Valuing changes in the quality of coral reef ecosystems: a stated preference study of SCUBA diving in the Bonaire National Marine Park. Environ. Resour. Econ. 40:593-608. Article

Pinhey, T. K., D. H. Rubinstein, and S. M. Vaughn.

2006. Fishing and fiestas in Guam: an exploratory note on the reinforcement of cultural traditions. Pacific Studies 29:74-82.

Plagányi, É. E., I. van Putten, T. Hutton, R. A. Deng, D. Dennis, S. Pascoe, T. Skewes, and R. A. Campbell.

2013. Integrating indigenous livelihood and lifestyle objectives in managing a natural resource. Proc. Natl. Acad. Sci. 110:3639-3644. Article

Richards, B. L., I. D. Williams, M. O. Nadon, and B. J. Zgliczynski.

2011. A towed-diver survey method for mesoscale fishery-independent assessment of large-bodied reef fishes. Bull. Mar. Sci. 87:55-74. Article

Ruttenberg, B. I., S. L. Hamilton, S. M. Walsh, M. K. Donovan,

A. Friedlander, E. DeMartini, E. Sala, and S. A. Sandin.

2011. Predator-induced demographic shifts in coral reef fish assemblages. PLoS ONE 6(6):e21062. Article

Sabater, M., and P. Kleiber.

2014. Augmented catch-MSY approach to fishery management in coral-associated fisheries. In Interrelationships between corals and fisheries (S. A. Bortone, ed.), p. 199218. CRC Press, Boca Raton, FL.

Sadovy, Y.

2005. Trouble on the reef: the imperative for managing vulnerable and valuable fisheries. Fish Fish. 6:167185. Article

Taylor, B. M., and J. H. Choat.

2014. Comparative demography of commercially important parrotfish species from Micronesia. J. Fish Biol. 84:383-402. Article

Taylor, B. M., J. L. McIlwain, and A. M. Kerr.

2012. Marine reserves and reproductive biomass: a case study of a heavily targeted reef fish. PLoS ONE 7(6):e39599. Article

Warren-Rhodes, K., Y. Sadovy, and H. Cesar.

2003. Marine ecosystem appropriation in the Indo-Pacific: a case study of the live reef fish food trade. Ambio 32:481-488.

Williams, I. D., J. K. Baum, A. Heenan, K. M. Hanson, M. O. Nadon, and R. E. Brainard.

2015. Human, oceanographic and habitat drivers of central and western Pacific coral reef fish assemblages. PLoS ONE 10(4):e0120516. Article

Williams, I. D., B. L. Richards, S. A. Sandin, J. K. Baum, R. E. Schroeder, M. O. Nadon, B. Zgliczynski, P. Craig, J. L. McIlwain, and R. E. Brainard.

2011. Differences in reef fish assemblages between populated and remote reefs spanning multiple archipelagos across the central and western Pacific. J. Mar. Biol. 2011:Article ID 826234. Article

Williams, I., J. Zamzow, K. Lino, M. Ferguson, and E. Donham.

2012. Status of coral reef fish assemblages and benthic condition around Guam: a report based on underwater visual surveys in Guam and the Mariana Archipelago, April-June 2011. NOAA Tech. Memo. NMFS-PIFSC-33, $22 \mathrm{p}$.

Zeller D, S. Harper, K. Zylich, and D. Pauly.

2015. Synthesis of underreported small-scale fisheries catch in Pacific-island waters. Coral Reefs 34:25-39. Article

Zeller, D., S. Booth, G. Davis, and D. Pauly.

2007. Re-estimation of small-scale fishery catches for U.S. flag-associated island areas in the western Pacific: the last 50 years. Fish. Bull. 105:266-277. 


\section{Appendix 1}

\section{Boat-based and shore-based creel survey data}

Data on both boat- and shore-based fisheries are collected during creel surveys conducted by staff of the Guam Division of Aquatic and Wildlife Resources (DAWR). Boat-based fisheries are focused mainly on trolling for pelagic species and bottom fishing for deepwater (depths $>30 \mathrm{~m}$ ) species for commercial reasons, and shore-based fisheries target shallow-water reef fishes for recreational or cultural reasons. Landings of fishes associated with shallow (depths $\leq 30 \mathrm{~m}$ ) reefs-the focus of this study-accounted for $26 \%$ of the total catch of fishes for the boat-based fishery from 1985 through 2012 (based on data from the DAWR boat-based creel surveys). In the last 3 years for which complete data are available (2010-2012), average annual catches of reef fishes from shore-based fisheries were 63 metric tons (t), of which reef fish composed $43.5 \%$ and bigeye scad (Selar crumenopthalmus) made up 50.2\% (Appendix 1 Table). During the same time period, average annual catches from boat-based fisheries were $359 \mathrm{t}$, pelagic fishes accounted for $76.4 \%$ of the catch composition, and reef fishes accounted for $13.1 \%$.

Although landings of reef fishes from shore-based fishing activities accounted for just $37 \%$ of the total (boat-based and shore-based combined) reef-fish landings, the shallow-reef fish populations exploited in the shore-based fishery potentially are very important for subsistence or cultural reasons. Data from interviews from the shore-based fishery of the DAWR creel survey program revealed that only one fisherman sold the catch, on one occasion, during the period from 1985 through 2012. Because boat-based fisheries account for a large amount of reef fish catches, we first determined whether the trend in catches of just the shore-based fisheries was comparable with the trend in catches from the boat-based fisheries of reef fishes and, if so, whether the trend would be representative of the catches of coral reef fish.

The majority of the reef fishes captured in the boatbased fisheries were caught by spearfishing with snorkel and scuba (Appendix 1 Fig. 1), gear types used in both boat-based and shore-based fisheries. We visually compared the difference in trends of the standardized values of catches between boat-based and shore-based spearfishing (Appendix 1 Fig. 2). A Comparison of these trends from both fisheries indicates that only in about the first 4 years did values differ by 2-4 units but, beginning in 1988, values were very similar between the fisheries, leading us to conclude that the trends in catches reflect common changes in the target stocks as well.

\section{Appendix 1 Table}

Composition of catches from the boat-based and shorebased components of the creel survey conducted in Guam during 2010-2012. Other=invertebrates and unknown species. Data came from the Guam Division of Aquatic and Wildlife Resources and the Western Pacific Fisheries Information Network of the NOAA Pacific Islands Fisheries Science Center.

\begin{tabular}{lrrrrr}
\hline & \multicolumn{2}{c}{ Boat-based fishery } & & \multicolumn{2}{c}{ Shore-based fishery } \\
\cline { 2 - 3 } \cline { 5 - 6 } Species & $\begin{array}{c}\text { Portion } \\
\text { of } \\
\text { catch }(\%)\end{array}$ & $\begin{array}{c}\text { Average } \\
\text { annual } \\
\text { catch }(\mathrm{kg})\end{array}$ & & $\begin{array}{c}\text { Portion } \\
\text { of } \\
\text { catch }(\%)\end{array}$ & $\begin{array}{c}\text { Average } \\
\text { annual } \\
\text { catch }(\mathrm{kg})\end{array}$ \\
\hline Reef fishes & 13.1 & 47,021 & & 43.5 & 27,465 \\
Pelagic fishes & 76.4 & 274,129 & & 0.6 & 395 \\
Bottom fishes & 3.3 & 11,729 & & 0.0 & 5 \\
Bigeye scad & 6.9 & 24,754 & & 50.2 & 31,714 \\
Other & 0.3 & 947 & & 5.7 & 3614 \\
Total & 100.0 & 358,579 & & 100.0 & 63,193 \\
& & & & \\
\hline
\end{tabular}

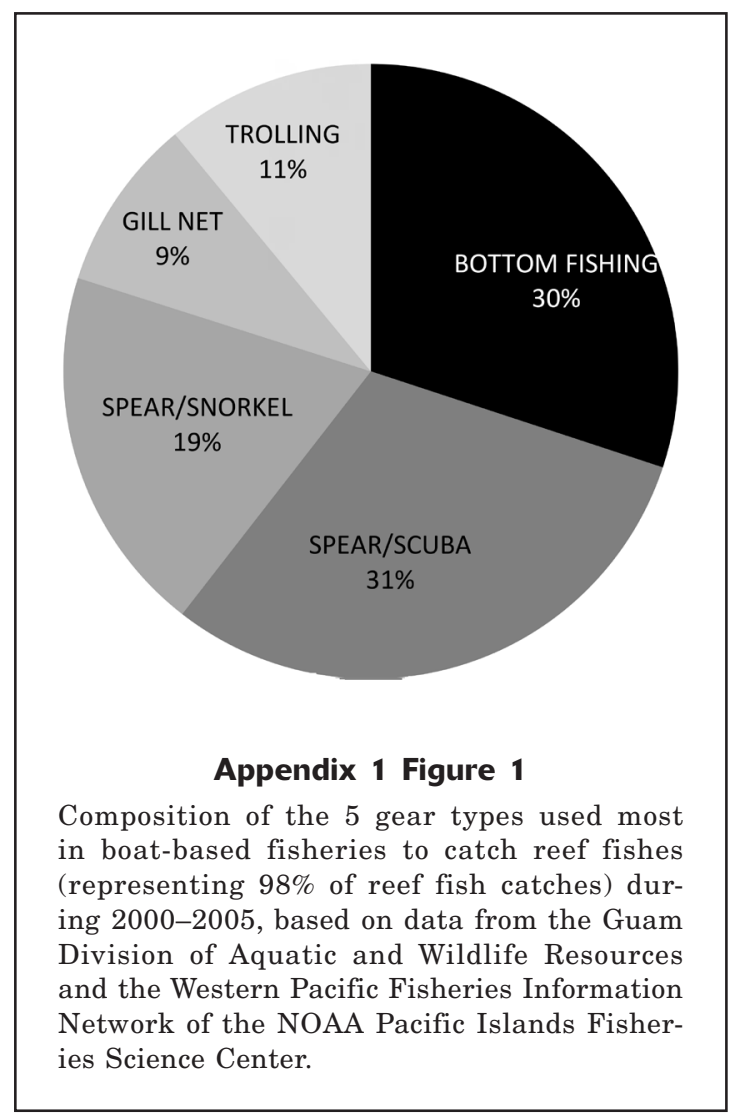




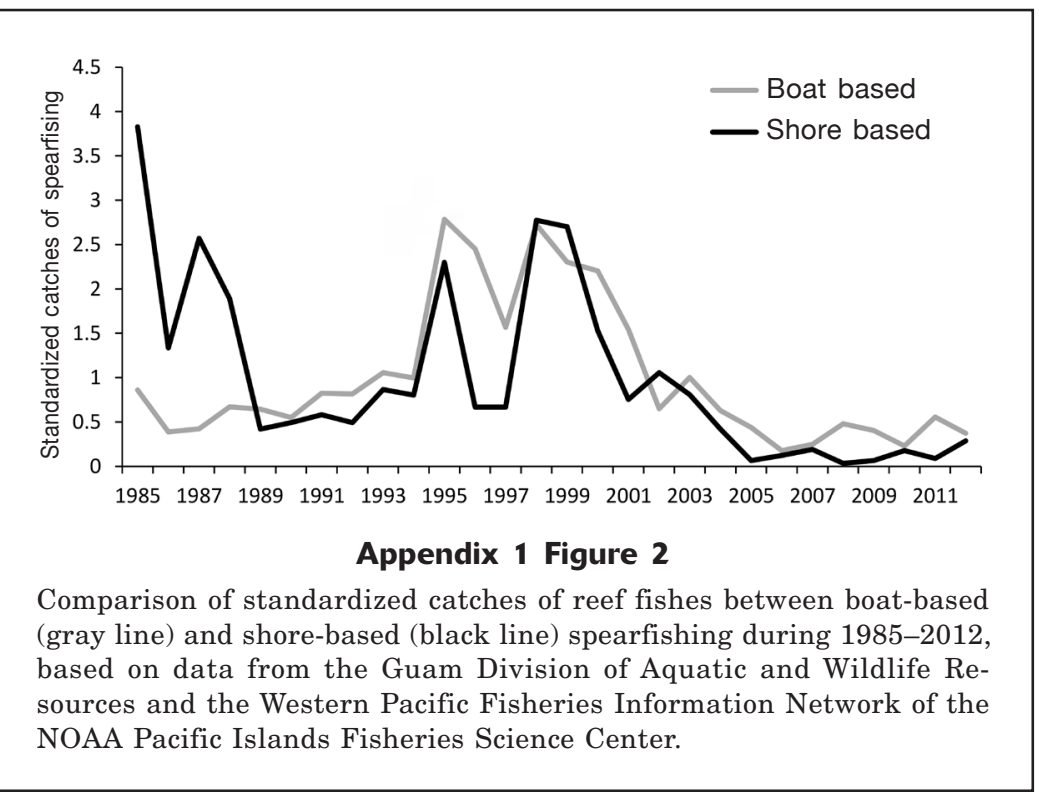

\section{Appendix 2}

\section{Shore-based creel surveys}

For reporting purposes of the shore-based fishery of the creel survey program of the Guam Division of Aquatic and Wildlife Resources, Guam has been divided into 93 fishing sites that are grouped into 4 coastal regions (Appendix 2 Figure):

- Region 1 consists of the northwestern portion of Guam from Gun Beach to Adelup (sites 1-11)

- Region 2 consists of the southwestern portion of Guam from Adelup to Agat (sites 12-34, excluding inaccessible sites 35-41)

- Region 3 consists of the central-eastern to southern portion of Guam from Pago Bay to Merizo (sites 4271, excluding inaccessible sites 57-60)

- Region 4 consists of the northern part of Guam, and access is restricted there because of a military base (sites 72-93)

The staff of the Western Pacific Fisheries Information Network (WPacFIN), NOAA Pacific Islands Fisheries Science Center, provides assistance with fishery statistics to partners at the Guam Division of Aquatic and
Wildlife Resources and has developed an expansion algorithm to extrapolate results of the shore-based creel surveys into estimates of island-wide catch and effort. The shore-based creel surveys have 2 parts, interviews of a sample of fishermen and surveys where fishing activities were observed and recorded (participation surveys). Staff of the WPacFIN estimated annual fishing effort (measured in gear hours) per gear type per region by multiplying the total number of gear hours fished, from observations in the participation survey, by 2 correction factors 1 ) the ratio of the number of days in a year to the total number of scheduled survey days and 2) the number of available fishing hours in the morning and in the evening (Bak, footnote 1 in the main text). Staff of the WPacFIN estimated total annual catch per gear per region as the product of total annual effort and the gear- and region-specific average catch per unit effort (CPUE), the latter derived within each stratum as total sampled catch divided by total sampled effort. The estimated total catch per species within each stratum was calculated by multiplying aggregate annual catch by the ratio of that particular species in the catch from the interviews $\left(\mathrm{Bak}^{12}\right)$. Missing CPUE data was substituted with a moving average of the previous 10 years of CPUE data. 


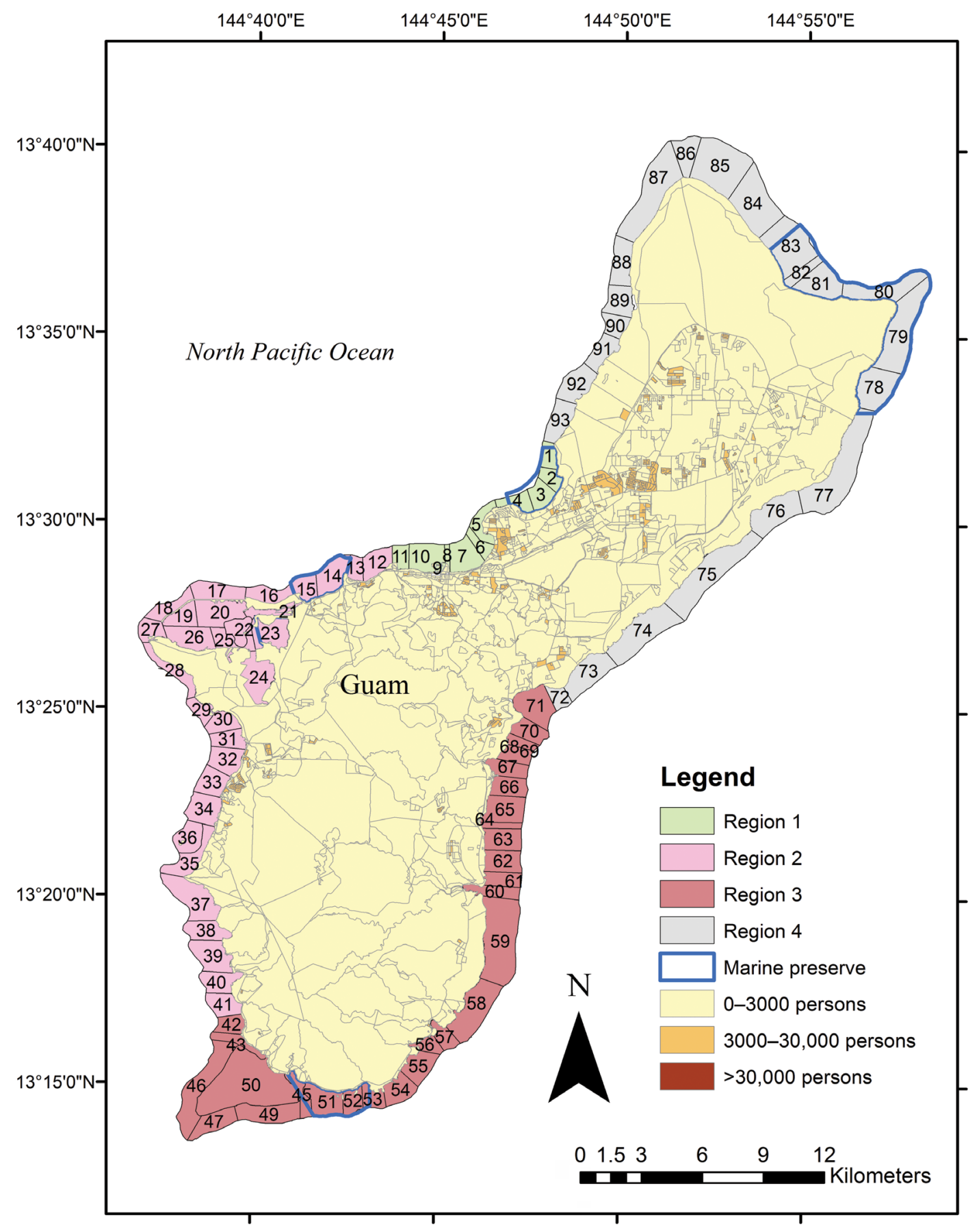

Appendix 2 Figure

Map of the fishery regions and sites around Guam where data were collected during shorebased creel surveys conducted by the Guam Division of Aquatic and Wildlife Resources (DAWR), based on a GIS shapefile of fishery sites from the DAWR. 


\section{Appendix 3}

Interviews and catch per unit of effort

\section{Appendix 3 Table 1}

Number of interviews conducted as part of shore-based creel surveys conducted around Guam, per gear type per year. For some gear types in some years, the total number of interviews was between 1 and 4 or $<5$.

\begin{tabular}{|c|c|c|c|c|c|c|c|c|c|c|c|c|c|c|c|}
\hline & 1985 & 1986 & 1987 & 1988 & 1989 & 1990 & 1991 & 1992 & 1993 & 1994 & 1995 & 1996 & 1997 & 1998 & 1999 \\
\hline Hook and line & 53 & 46 & 32 & 38 & 45 & 59 & 63 & 66 & 61 & 83 & 78 & 76 & 87 & 84 & 85 \\
\hline Gill net & 38 & 34 & 28 & 28 & 25 & 41 & 35 & 40 & 33 & 36 & 49 & 31 & 50 & 48 & 51 \\
\hline Surround net & 7 & $<5$ & $<5$ & 5 & 0 & $<5$ & 0 & $<5$ & 0 & $<5$ & $<5$ & 0 & 0 & 0 & 0 \\
\hline Snorkel spear & 35 & 20 & 21 & 18 & 14 & 14 & 15 & 16 & 14 & 36 & 21 & 20 & 25 & 34 & 49 \\
\hline Scuba spear & $<5$ & $<5$ & 0 & $<5$ & $<5$ & $<5$ & $<5$ & $<5$ & $<5$ & $<5$ & 9 & $<5$ & $<5$ & $<5$ & $<5$ \\
\hline \multirow[t]{2}{*}{ Drag net } & 8 & 9 & 8 & $<5$ & $<5$ & 5 & 7 & 7 & 6 & $<5$ & 5 & $<5$ & $<5$ & $<5$ & 10 \\
\hline & 2000 & 2001 & 2002 & 2003 & 2004 & 2005 & 2006 & 2007 & 2008 & 2009 & 2010 & 2011 & 2012 & & \\
\hline Hook and line & 86 & 86 & 60 & 78 & 61 & 60 & 65 & 61 & 64 & 62 & 57 & 48 & 45 & & \\
\hline Gill net & 41 & 31 & 28 & 16 & 15 & 13 & 13 & 11 & 12 & 6 & 13 & 12 & 9 & & \\
\hline Surround net & 0 & 0 & 0 & $<5$ & $<5$ & 0 & $<5$ & $<5$ & $<5$ & 0 & $<5$ & $<5$ & 0 & & \\
\hline Snorkel spear & 28 & 27 & 19 & 14 & 10 & 8 & 9 & 5 & 6 & 5 & 7 & $<5$ & 11 & & \\
\hline Scuba spear & $<5$ & $<5$ & $<5$ & $<5$ & 0 & 0 & 0 & 0 & 0 & 0 & $<5$ & 0 & 0 & & \\
\hline Drag net & 4 & $<5$ & 0 & 0 & 0 & $<5$ & $<5$ & 0 & 0 & 0 & 0 & 0 & 0 & & \\
\hline
\end{tabular}

\section{Appendix 3 Table 2}

Annual values of catch per unit of effort around Guam, by gear type and year, calculated by the Western Pacific Fisheries Information Network, NOAA Pacific Islands Fisheries Science Center, from data collected during shore-based creel surveys.

Values in bold are the mean of the 3 previous years for values that were missing in the survey-data..

\begin{tabular}{lcccccccccccccccc}
\hline & 1985 & 1986 & 1987 & 1988 & 1989 & 1990 & 1991 & 1992 & 1993 & 1994 & 1995 & 1996 & 1997 & 1998 & 1999 \\
\hline Hook and line & 0.18 & 0.21 & 0.20 & 0.09 & 0.11 & 0.14 & 0.16 & 0.09 & 0.06 & 0.09 & 0.14 & 0.08 & 0.10 & 0.10 & 0.11 \\
Gill net & 1.19 & 1.16 & 1.11 & 1.76 & 1.08 & 1.18 & 0.94 & 0.85 & 0.45 & 0.64 & 0.61 & 0.48 & 0.49 & 0.29 & 0.51 \\
Surround net & 1.79 & 3.07 & 0.48 & 1.19 & 0.72 & 0.93 & 0.93 & 0.93 & 0.37 & 2.14 & 0.65 & 0.65 & 0.51 & 0.51 & 0.93 \\
Snorkel spear & 1.50 & 0.87 & 0.71 & 0.58 & 0.49 & 0.43 & 0.53 & 0.72 & 0.92 & 0.88 & 0.82 & 0.49 & 0.73 & 1.73 & 0.87 \\
Scuba spear & 1.25 & $\mathbf{1 . 2 5}$ & 1.25 & 0.53 & 0.89 & 0.34 & 0.40 & 0.32 & 0.34 & 0.34 & 2.04 & 0.32 & 0.34 & 0.64 & 0.29 \\
Drag net & 1.11 & 1.23 & 0.95 & 0.20 & 2.66 & 0.91 & 2.06 & 2.96 & 0.91 & 2.11 & 1.54 & $\mathbf{1 . 5 2}$ & 1.42 & 1.83 & 1.66 \\
\hline & 2000 & 2001 & 2002 & 2003 & 2004 & 2005 & 2006 & 2007 & 2008 & 2009 & 2010 & 2011 & 2012 & \\
\hline Hook and line & 0.08 & 0.08 & 0.07 & 0.09 & 0.08 & 0.05 & 0.08 & 0.09 & 0.06 & 0.07 & 0.03 & 0.09 & 0.14 \\
Gill net & 0.62 & 0.50 & 0.46 & 0.35 & 0.25 & 0.66 & 0.18 & 0.45 & 0.63 & 0.15 & 1.26 & 0.09 & 0.77 \\
Surround net & 0.65 & 0.93 & 0.65 & 0.37 & 0.93 & 0.93 & 0.65 & 0.65 & 0.51 & 0.93 & 0.51 & 0.93 & 0.51 & \\
Snorkel spear & 0.64 & 0.91 & 0.91 & 1.49 & 0.74 & 0.29 & 0.47 & 0.40 & 0.12 & 0.12 & 0.06 & 0.06 & 0.38 \\
Scuba spear & 0.32 & 0.40 & 0.40 & 0.24 & 0.40 & 0.34 & 0.32 & 0.40 & $\mathbf{0 . 3 5}$ & $\mathbf{0 . 3 5}$ & $\mathbf{0 . 3 7}$ & 0.40 & 0.24 & \\
Drag net & 0.31 & 1.21 & 0.91 & $\mathbf{0 . 8 1}$ & 2.11 & 0.31 & $\mathbf{1 . 0 8}$ & 0.31 & $\mathbf{0 . 5 6}$ & 2.11 & $\mathbf{0 . 9 9}$ & 0.91 & 0.31 & \\
\end{tabular}




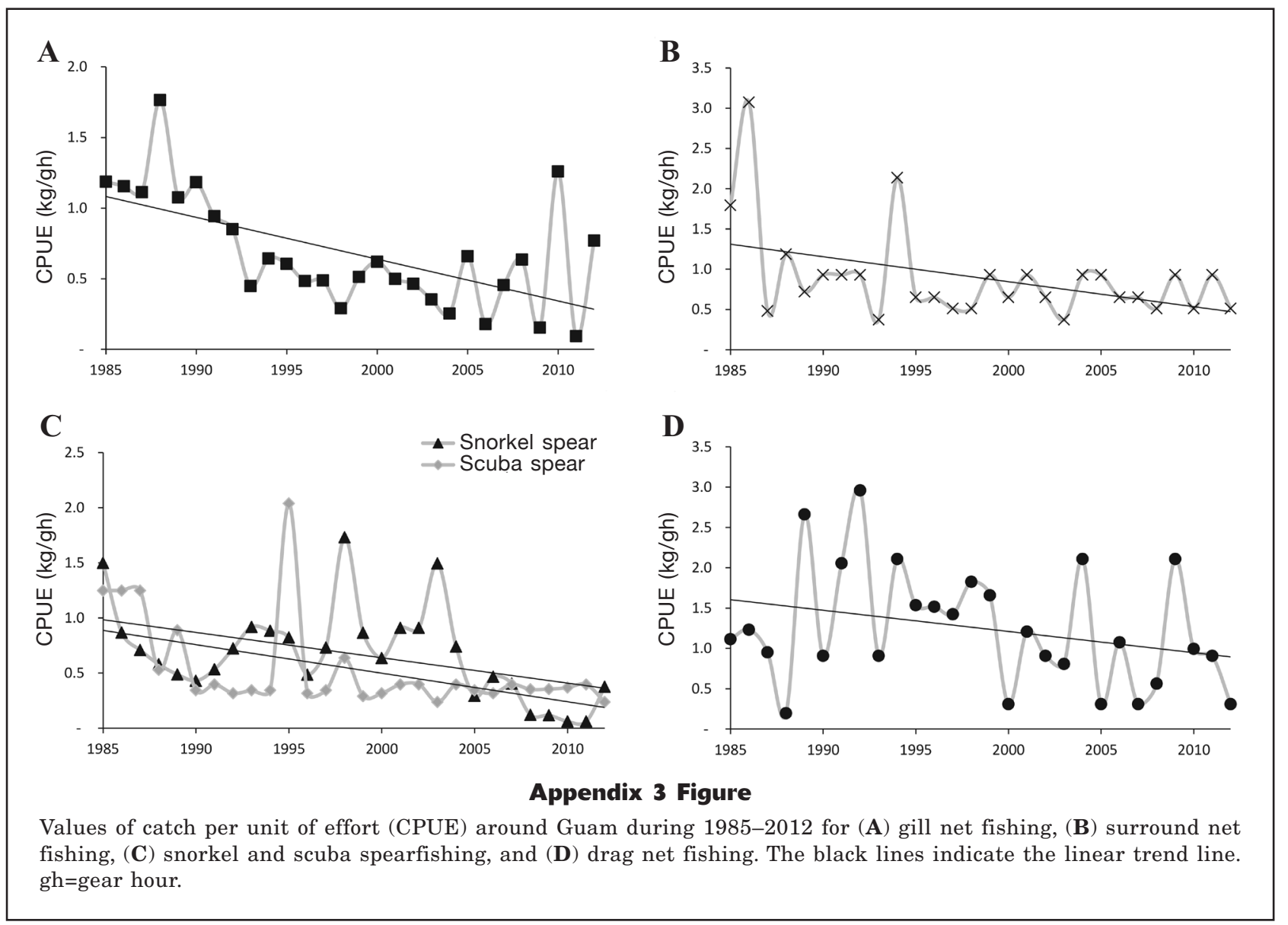

\section{Appendix 4}

\section{Number of times landings included each functional group}

The tables in this appendix provide the number of times that a functional group, as defined in Table 1 in the main text, was recorded from landings data for 3-year periods from interviews of shore-based creel surveys conducted around Guam from 1985 through 2012. Data are provided over 3-year periods to preserve the confidentiality of the identities of fishermen. Blank cells indicate that no interview took place in that period.

\begin{tabular}{|c|c|c|c|c|c|c|}
\hline \multicolumn{7}{|c|}{ Appendix 4 Table } \\
\hline & Drag net & Gill net & $\begin{array}{c}\text { Hook } \\
\text { and line }\end{array}$ & $\begin{array}{l}\text { Scuba } \\
\text { spear }\end{array}$ & $\begin{array}{l}\text { Snorkel } \\
\text { spear }\end{array}$ & $\begin{array}{c}\text { Surround } \\
\text { net }\end{array}$ \\
\hline \multicolumn{7}{|c|}{ Scrapers (small-bodied parrotfishes) } \\
\hline 1985-1987 & 0 & 10 & 2 & 4 & 61 & 2 \\
\hline $1988-1990$ & 0 & 7 & 0 & 0 & 18 & 0 \\
\hline $1991-1993$ & 0 & 39 & 3 & 1 & 18 & 0 \\
\hline 1994-1996 & 0 & 34 & 5 & 6 & 53 & 5 \\
\hline 1997-1999 & 1 & 54 & 8 & 5 & 120 & \\
\hline $2000-2002$ & 0 & 16 & 7 & 6 & 39 & 0 \\
\hline $2003-2005$ & 0 & 7 & 1 & 3 & 20 & 0 \\
\hline $2006-2008$ & 0 & 4 & 2 & & 14 & 0 \\
\hline 2009-2011 & & 3 & 0 & 2 & 5 & 0 \\
\hline \multirow[t]{2}{*}{ 2012-2013 } & & 3 & 0 & & 8 & 0 \\
\hline & & & & & \multicolumn{2}{|c|}{ Table continuec } \\
\hline
\end{tabular}




\begin{tabular}{|c|c|c|c|c|c|c|}
\hline \multicolumn{7}{|c|}{ Appendix 4 Table continued } \\
\hline & Drag net & Gill net & $\begin{array}{c}\text { Hook } \\
\text { and line }\end{array}$ & $\begin{array}{l}\text { Scuba } \\
\text { spear }\end{array}$ & $\begin{array}{c}\text { Snorkel } \\
\text { spear }\end{array}$ & $\begin{array}{c}\text { Surround } \\
\text { net }\end{array}$ \\
\hline \multicolumn{7}{|c|}{ Excavators (large-bodied parrotfishes) } \\
\hline 1985-1987 & 0 & 3 & 0 & 0 & 24 & 0 \\
\hline $1988-1990$ & 0 & 2 & 0 & 0 & 7 & 0 \\
\hline $1991-1993$ & 0 & 8 & 2 & 4 & 8 & 0 \\
\hline $1994-1996$ & 0 & 4 & 3 & 7 & 21 & 0 \\
\hline 1997-1999 & 0 & 6 & 6 & 5 & 39 & \\
\hline $2000-2002$ & 0 & 1 & 2 & 2 & 25 & 0 \\
\hline $2003-2005$ & 0 & 1 & 4 & 1 & 4 & 0 \\
\hline 2006-2008 & 0 & 1 & 2 & & 1 & 0 \\
\hline 2009-2011 & & 0 & 2 & 0 & 3 & 0 \\
\hline $2012-2013$ & & 0 & 0 & & 3 & 0 \\
\hline \multicolumn{7}{|c|}{ Target browsers (e.g., unicornfishes, rabbitfishes) } \\
\hline 1985-1987 & 11 & 92 & 68 & 10 & 198 & 24 \\
\hline $1988-1990$ & 6 & 112 & 85 & 1 & 137 & 2 \\
\hline $1991-1993$ & 2 & 104 & 116 & 4 & 46 & 4 \\
\hline 1994-1996 & 3 & 80 & 114 & 20 & 129 & 4 \\
\hline $1997-1999$ & 10 & 145 & 138 & 12 & 229 & \\
\hline $2000-2002$ & 5 & 102 & 127 & 6 & 145 & 0 \\
\hline $2003-2005$ & 0 & 28 & 47 & 7 & 51 & 2 \\
\hline $2006-2008$ & 1 & 28 & 39 & & 30 & 1 \\
\hline 2009-2011 & & 23 & 24 & 1 & 20 & 2 \\
\hline 2012-2013 & & 8 & 9 & & 19 & 0 \\
\hline \multicolumn{7}{|c|}{ Target grazers (e.g., surgeonfishes) } \\
\hline 1985-1987 & 1 & 67 & 18 & 2 & 80 & 5 \\
\hline $1988-1990$ & 2 & 90 & 14 & 0 & 72 & 2 \\
\hline $1991-1993$ & 0 & 76 & 34 & 3 & 36 & 2 \\
\hline 1994-1996 & 0 & 76 & 28 & 9 & 84 & 2 \\
\hline 1997-1999 & 2 & 119 & 19 & 6 & 133 & \\
\hline 2000-2002 & 0 & 64 & 21 & 4 & 77 & 0 \\
\hline 2003-2005 & 0 & 25 & 26 & 1 & 29 & 1 \\
\hline 2006-2008 & 0 & 17 & 17 & & 16 & 1 \\
\hline 2009-2011 & & 10 & 9 & 0 & 8 & 3 \\
\hline 2012-2013 & & 4 & 5 & & 9 & 0 \\
\hline \multicolumn{7}{|c|}{ Target invertebrate-consuming fishes (e.g., emperors, goatfishes, snappers) } \\
\hline 1985-1987 & 60 & 258 & 46 & 2 & 151 & 32 \\
\hline $1988-1990$ & 23 & 274 & 85 & 1 & 79 & 3 \\
\hline $1991-1993$ & 44 & 337 & 203 & 6 & 62 & 2 \\
\hline 1994-1996 & 18 & 329 & 259 & 12 & 181 & 7 \\
\hline $1997-1999$ & 64 & 469 & 329 & 3 & 307 & \\
\hline $2000-2002$ & 14 & 305 & 255 & 13 & 163 & 0 \\
\hline $2003-2005$ & 1 & 77 & 136 & 8 & 47 & 4 \\
\hline $2006-2008$ & 1 & 29 & 117 & & 28 & 0 \\
\hline 2009-2011 & & 48 & 71 & 1 & 16 & 3 \\
\hline 2012-2013 & & 33 & 29 & & 29 & 0 \\
\hline \multicolumn{7}{|c|}{ Target benthic piscivores (e.g., groupers) } \\
\hline 1985-1987 & 1 & 10 & 8 & 1 & 31 & 1 \\
\hline $1988-1990$ & 0 & 39 & 33 & 1 & 32 & 0 \\
\hline 1991-1993 & 0 & 55 & 93 & 2 & 26 & 1 \\
\hline 1994-1996 & 0 & 22 & 61 & 3 & 47 & 2 \\
\hline 1997-1999 & 0 & 32 & 68 & 1 & 71 & \\
\hline 2000-2002 & 0 & 24 & 72 & 2 & 40 & 0 \\
\hline 2003-2005 & 0 & 4 & 66 & 2 & 13 & 0 \\
\hline 2006-2008 & 0 & 4 & 46 & & 10 & 0 \\
\hline 2009-2011 & & 2 & 17 & 0 & 2 & 1 \\
\hline \multirow[t]{2}{*}{ 2012-2013 } & & 2 & 6 & & 6 & 0 \\
\hline & & & & & \multicolumn{2}{|c|}{ Table continued } \\
\hline
\end{tabular}




\begin{tabular}{|c|c|c|c|c|c|c|}
\hline \multicolumn{7}{|c|}{ Appendix 4 Table continued } \\
\hline & Drag net & Gill net & $\begin{array}{c}\text { Hook } \\
\text { and line }\end{array}$ & $\begin{array}{l}\text { Scuba } \\
\text { spear }\end{array}$ & $\begin{array}{l}\text { Snorkel } \\
\text { spear }\end{array}$ & $\begin{array}{c}\text { Surround } \\
\text { net }\end{array}$ \\
\hline \multicolumn{7}{|c|}{ Mid-water piscivores (e.g., needlefishes, Heller's barracuda [Sphyraena helleri]) } \\
\hline 1985-1987 & 13 & 16 & 17 & 1 & 4 & 7 \\
\hline $1988-1990$ & 6 & 9 & 25 & 0 & 1 & 0 \\
\hline 1991-1993 & 6 & 22 & 25 & 0 & 4 & 0 \\
\hline $1994-1996$ & 4 & 20 & 29 & 0 & 6 & 1 \\
\hline 1997-1999 & 12 & 25 & 25 & 0 & 19 & \\
\hline 2000-2002 & 2 & 5 & 25 & 0 & 10 & 0 \\
\hline $2003-2005$ & 2 & 4 & 23 & 0 & 4 & 0 \\
\hline $2006-2008$ & 2 & 4 & 7 & & 2 & 0 \\
\hline $2009-2011$ & & 5 & 14 & 0 & 1 & 1 \\
\hline $2012-2013$ & & 3 & 0 & & 3 & 0 \\
\hline \multicolumn{7}{|c|}{ Roving piscivores (e.g., jacks) } \\
\hline 1985-1987 & 27 & 76 & 71 & 1 & 9 & 5 \\
\hline 1988-1990 & 13 & 84 & 78 & 1 & 3 & 5 \\
\hline $1991-1993$ & 9 & 63 & 139 & 0 & 5 & 0 \\
\hline 1994-1996 & 11 & 73 & 234 & 0 & 3 & 1 \\
\hline 1997-1999 & 14 & 98 & 303 & 0 & 3 & \\
\hline 2000-2002 & 6 & 66 & 236 & 0 & 5 & 0 \\
\hline $2003-2005$ & 0 & 20 & 189 & 1 & 3 & 1 \\
\hline $2006-2008$ & 0 & 10 & 190 & & 1 & 2 \\
\hline 2009-2011 & & 19 & 132 & 0 & 1 & 0 \\
\hline $2012-2013$ & & 13 & 89 & & 1 & 0 \\
\hline
\end{tabular}

\section{Appendix 5}

\section{Comparison of catch per unit of effort between day types}

Results from analysis in this study revealed a significant difference between weekday and weekend hookand-line fishing in regions 1 and 2 (for location of these regions, see Appendix 1, Fig. 1). Comparisons of catch per unit of effort (CPUE) per day type for all regions combined and the gear types cast net, gill net, and snorkel spear did not show a significant difference $(P \geq 0.05)$ between weekday and weekend fishing. There were not enough data to compare weekday and weekend CPUE for the remaining gear types.

\section{Appendix 5 Table}

Comparison of catch per unit of effort (CPUE) per gear type between day types (weekday and weekend) with a Welch 2-sample t-test (which allows for unequal variances) and between regions with analysis of variance (ANOVA) for the hook-and-line fishery around Guam. Values are means (and standard deviations [SD]) during 1985-2012. Region 0 is the combination of regions 1,2, 3 and 4. Values of CPUE are given in kilograms per gear hour.

\begin{tabular}{|c|c|c|c|c|c|c|c|c|}
\hline \multirow[b]{2}{*}{ Gear type } & \multirow[b]{2}{*}{ Region } & \multicolumn{2}{|c|}{ Mean CPUE (SD) } & \multicolumn{2}{|c|}{ Welch 2-sample $t$-test } & \multicolumn{3}{|c|}{ ANOVA } \\
\hline & & Weekday & Weekend & $P$ & $n$ & Mean CPUE & $P$ & $n$ \\
\hline \multirow[t]{3}{*}{ Hook and line } & 1 & $0.12(0.09)$ & $0.07(0.05)$ & 0.02 & 28 & $0.09(0.06)$ & 0.37 & 28 \\
\hline & 2 & $0.10(0.07)$ & $0.07(0.04)$ & 0.04 & 28 & $0.09(0.05)$ & & \\
\hline & 3 & $0.12(0.08)$ & $0.09(0.05)$ & 0.10 & 28 & $0.11(0.05)$ & & \\
\hline Cast net & 0 & $0.25(0.18)$ & $0.22(0.14)$ & 0.45 & 28 & & & \\
\hline Gill net & 0 & $0.65(0.47)$ & $0.71(0.47)$ & 0.62 & 28 & & & \\
\hline Snorkel spear & 0 & $0.75(0.57)$ & $0.59(0.37)$ & 0.23 & 28 & & & \\
\hline
\end{tabular}

